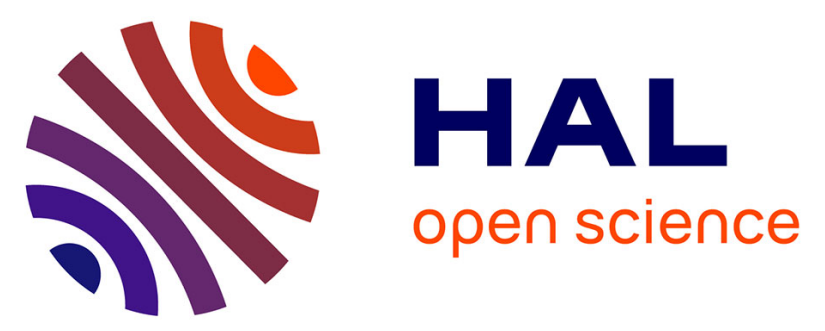

\title{
A comparison of cooling-limited and volume-limited flow systems: Examples from channels in the Piton de la Fournaise April 2007 lava-flow field
}

\author{
Maéva Rhéty, Andrew Harris, Nicolas Villeneuve, Lucia Gurioli, Etienne \\ Médard, Magdalena Oryaëlle Chevrel, Patrick Bachèlery
}

\section{To cite this version:}

Maéva Rhéty, Andrew Harris, Nicolas Villeneuve, Lucia Gurioli, Etienne Médard, et al.. A comparison of cooling-limited and volume-limited flow systems: Examples from channels in the Piton de la Fournaise April 2007 lava-flow field. Geochemistry, Geophysics, Geosystems, 2017, 18 (9), pp.3270 3291. 10.1002/2017GC006839 . hal-01634863

\section{HAL Id: hal-01634863 \\ https://hal.uca.fr/hal-01634863}

Submitted on 28 Jun 2018

HAL is a multi-disciplinary open access archive for the deposit and dissemination of scientific research documents, whether they are published or not. The documents may come from teaching and research institutions in France or abroad, or from public or private research centers.
L'archive ouverte pluridisciplinaire HAL, est destinée au dépôt et à la diffusion de documents scientifiques de niveau recherche, publiés ou non, émanant des établissements d'enseignement et de recherche français ou étrangers, des laboratoires publics ou privés. 


\section{Geochemistry, Geophysics, Geosystems}

\section{RESEARCH ARTICLE \\ 10.1002/2017GC006839 \\ Key Points: \\ - We define the morphological \\ A comparison of cooling-limited and volume-limited flow systems: Examples from channels in the Piton de la Fournaise April 2007 lava-flow field} differences between volume-limited and cooling-limited lava flow

-We define down-flow cooling and crystallization in a cooling-limited and a volume-limited channel -We propose a data-driven model for emplacement of a cooling-limited flow field fed by multiple short-lived effusive events

Supporting Information:

- Table S1

Correspondence to:

A. Harris,

andrew.harris@uca.fr

Citation:

Rhéty, M., A. Harris, N. Villeneuve, L. Gurioli, E. Médard, O. Chevrel, and P. Bachélery (2017), A comparison of cooling-limited and volume-limited flow systems: Examples from channels in the Piton de la Fournaise April 2007 lava-flow field, Geochem. Geophys. Geosyst., 18, 3270-3291, doi:10.1002/ 2017GC006839.

Received 26 JAN 2017 Accepted 7 JUL 2017 Accepted article online 21 JUL 2017 Published online 1 SEP 2017

\author{
Maéva Rhéty' ${ }^{1}$ Andrew Harris', Nicolas Villeneuve², Lucia Gurioli1, Etienne Médard1, \\ Oryaëlle Chevrel ${ }^{1}$ (D), and Patrick Bachélery ${ }^{1}$
} GéoSciences Réunion, Saint Denis Messagerie, La Réunion, France cut; effectively the tap is turned off. We term the former "cooling-limited" flows, and the latter "volume
${ }^{1}$ Université Clermont Auvergne, CNRS, IRD, OPGC, Laboratoire Magmas et Volcans, Clermont-Ferrand, France, ${ }^{2}$ Laboratoire

\begin{abstract}
Channel-fed lava-flow systems lack detailed thermal and textural studies through the boundary between channelized and dispersed flow, and out to the flow front. Here chemical, textural, and morphological analyses were made to define cooling and crystallization rates down the entire system, especially through the zone of dispersed flow. We compare two channel systems active during the 2007 eruption of Piton de la Fournaise, one of which was cooling limited and one of which as volume limited. In the cooling-limited case, rapid changes in rheology occurred across the zone of dispersed flow, where viscosity increased from 1000 to $1600 \mathrm{~Pa}$ s over the last $100 \mathrm{~m}$ of the channel system. This was due to an increase in cooling rate from $7^{\circ} \mathrm{C} \mathrm{km}^{-1}$ over the first $500 \mathrm{~m}$ of the system, to $42^{\circ} \mathrm{C} \mathrm{km}^{-1}$ over the last $100 \mathrm{~m}$, and an increase in microcryst content from $13 \%$ to $25 \%$. In the volume-limited case, the exponentially increasing segment of the down-flow cooling and viscosity trend is absent. Instead, lava arriving at the flow front is still relatively hot $\left(1161^{\circ} \mathrm{C}\right.$ compared with a near-vent temperature of $\left.1167^{\circ} \mathrm{C}\right)$ and is thus of relatively low viscosity (1125 Pa s). In the volume-limited case, because the channel was still in extension when supply to the system was cut, the zone of dispersed flow was extremely short. However, because lava behind the stalled flow front was still hot and fluid, breakouts from the static front resulted in a complex flow front morphology.
\end{abstract}

Plain Language Summary When lava flows stop they either do so because they have cooled to such an extent that they, essentially, freeze and thus can no longer move, or because the supply of lava is limited." We show here the differences in terms of rates of down-flow cooling and crystallization between the two flow types and point to the differences in appearance of the two. For the cooling-limited case, the channel feeds a zone of lava flow with well-formed, frozen flow fronts. For the volume-limited case, the channel extends all the way to the flow front, which is-itself-a mess because of fluid lava inside the stalled flow that then escapes through the stationary front. We show this through a study of lava flows emplaced during the largest historical eruption of Piton de la Fournaise, on the French island of Réunion; this being the eruption of April 2007.

\section{Introduction}

Following Mauna Loa's 1984 eruption Lipman and Banks [1987] used the spatial distribution of flow segments, distinguished by their differing morphologies and associated flow dynamics, to build a fourfold system for channel-fed lava flow. Down this system, morphologies were shown to evolve from well-formed, mature and stable near the vent, to poorly formed, immature and unstable near the flow front, i.e., channel form was still evolving with time near the flow front, but not near the vent. This system, hereafter termed the "L\&B channel system," has proved to be an exceedingly robust spatial framework within which channelfed flow systems can be described, having been proved applicable at basaltic channel-fed flow systems found in Hawaii, as well as on Piton de la Fournaise, the Galapagos Islands, Etna and even Olympus Mons [e.g., Kilburn and Guest, 1993; Wadge and Lopez, 1991]. L\&B systems can also be found in high-viscosity, silicic lava-flow fields, as at Santiaguito in Guatemala [Harris et al., 2004], and at spatial scales ranging from hundreds of kilometers down to a few meters. See, for example, Ball et al. [2008, Figure 8] which shows all (c) 2017. American Geophysical Union. All Rights Reserved. 
four segments of the L\&B system in an active pahoehoe lobe just $4 \mathrm{~m}$ long. These four segments that comprise an L\&B channel system are as follows:

1. A proximal, stable, channel zone where levées are well-developed, static and of a mature, compound morphology [Harris et al., 2009]; that is, being a mixture of initial, rubble, overflow, and accretionary levees [Sparks et al., 1976].

2. A medial, transitional, channel zone where flow is channelized and movement is contained between two zones of quasi-static, but still deformable, lava; so that the levées are not well formed.

3. A distal dispersed flow zone, where there are no levées so that lava is moving across its entire flow width.

4. The terminus of the system is defined by a flow front. Termed the "flow toe" by Lipman and Banks [1987], this is the zone where the system is still in extension. Lipman and Banks [1987] noted that at rapidly moving fronts flow advanced by out-welling of fluid core lava, which formed a brecciated crust, and overrode the preexisting front. Instead, on gentler slopes broader zones of dispersed flow occurred below a channelized flow zone and the flow front moved more slowly, had a greater thickness and an irregular profile, and consisted of denser blockier lava [Lipman and Banks, 1987, p. 1533].

L\&B channel systems will be cooling or volume limited. While for cooling-limited flow lava stops moving through the system because it has cooled to such an extent that further movement is rheologically impossible, in a volume-limited system flow stops because the supply of lava from the vent is cut [Guest et al., 1987]. The volume-limited condition emplaces shorter lava flows under any given effusion rate than the cooling-limited case, because the system does not have the time to reach its maximum, rheologically defined, length [Harris and Rowland, 2009]. Instead, cooling-limited conditions favor the emplacement of increasingly complex, compound lava-flow fields [e.g. Kilburn and Lopes, 1988, 1991]. We thus suggest that the spatial distribution of morphological components down an L\&B system, and the length of each segment, changes depending on whether emplacement is cooling or volume limited.

Key to such a comparison is the definition of the transitional zone, and especially the thermal, rheological, and flow dynamic changes that occur across the end of the channelized segment and into the zone of dispersed flow. Previous studies have focused on morphological, rheological and textural down-system changes across the stable and transitional-channel segments [Lipman and Banks, 1987; Moore, 1987; Crisp et al., 1994; Cashman et al., 1999; Soule et al., 2004; Riker et al., 2009; Robert et al., 2014]. These studies indicate a slow but steady increase in microcryst content, and a decrease in temperature and vesicle content, leading to an increase in viscosity across these proximal and medial flow sections. However, modeling has indicated that changes occur faster across the distal section of the channel-fed flow system, with cooling, crystallization, and viscosity increasing exponentially across the transition to dispersed flow [Harris and Rowland, 2001, 2015; Harris et al., 2007]. Unfortunately, the dispersed and transitional flow segments of the L\&B system has been poorly studied, so that little data are available to quantify the changes across this zone. Favalli et al. [2010a] defined the morphological changes between the end of the stable channel and the flow front at Etna's 2001 lava field, showing that morphological changes between the stable, transitional, and dispersed flow zones were abrupt. However, no study has focused on sampling, measuring, or quantifying the thermal, rheological, and flow dynamic changes across this crucial zone of transition from channelized-to-dispersed flow.

The aim of this study is thus to examine cooling and crystallization rates down a channel-fed flow system and to characterize the rheological and morphological changes across the transition from channelized-todispersed flow. Fundamentally, we seek to understand whether, and if so how, changes differ across the channelized-to-dispersed flow transition between cooling-limited and volume-limited cases. To complete this work, we focus on two channel-fed lava-flow units emplaced within the 2007 lava field of Piton de la Fournaise (La Réunion Island, France). Determining whether these 2007 flows were volume or cooling limited was thus our first aim, followed by carrying out measurements to understand the thermal and rheological changes down L\&B systems in volume-limited or cooling-limited cases. To do this, we first needed to set up a geothermometer for Piton de la Fournaise (to obtain down-flow temperature change and hence cooling rates), as well as to sample regularly down-flow so as to check down lava glass chemistry, crystallinity, density, and vesicularity. These measurements were first used in modeling to help constrain rheology and define whether flow was cooling or volume limited, and then to assess whether, and how, volume or 
cooling limits on flow emplacement may modify the morphological, textural, thermal, and rheological trends down an L\&B system.

\section{Geological Setting}

Piton de la Fournaise (PdF) is an active shield volcano located on La Réunion Island in the Indian Ocean (Figure 1). Volcanism is due to a hotspot that built up a line of volcanoes from the Deccan Traps to La Réunion Island, with La Réunion Island comprising three volcanic centers [Lénat et al., 2012] of which PdF is the youngest. Piton de la Fournaise averages one eruption per year [Bachèlery et al., 2016], where almost all historic eruptions have occurred in the youngest caldera, the Enclos Fouqué [Peltier et al., 2009].

\subsection{The Basaltic Lava Flows of Piton de la Fournaise}

Lavas erupted at PdF are transitional basalt that can be divided into three groups [Lénat et al., 2012]:
i. aphyric basalts;
ii. oceanite; and
iii. midalkaline basalts.

Based on their dimensions, three size classes of crystals can be identified in the associated lavas [Welsch et al., 2009]:
i. macrocrysts of olivine (diameters $>0.5 \mathrm{~mm}$ );
ii. mesocrysts (diameter $=0.5-0.1 \mathrm{~mm}$ ) that are either olivine or an assemblage of clinopyroxene + plagio- clase; and
iii. microcrysts (diameters $<0.1 \mathrm{~mm}$ ) composed of olivine + clinopyroxene + plagioclase + Cr-spinel with Fe-Ti oxide.

Macrocrysts and mesocrysts are not xenocrysts [Famin et al., 2009] but are phenocrysts and antecrysts formed due to undercooling in a mush that crystallized at the cold margins of a shallow magma reservoir [Welsch et al., 2013]. The majority of microcrysts apparent upon eruption form in the magma chamber, in particular olivine and pyroxene form near the cold borders of the shallow (2-2.5 km) magma storage zone [Peltier et al., 2009; Lénat et al., 2012]. The occurrence of plagioclase and clinopyroxene clusters indicates that a small amount of plagioclase cocrystallized with clinopyroxene in the cooler margins of the chamber, but the majority of plagioclase formed in the conduit due to water exsolution during ascent [Welsch et al., 2009]. Quenched, glassy lava-flow surfaces sampled down a lava-flow system will also contain a second population of microcrysts grown during down-flow cooling [Soule et al., 2004; Riker et al., 2009; Robert et al., 2014]. This population will thus increase down-channel as the flow temperature decreases [Lipman and Banks, 1987; Crisp et al., 1994; Cashman et al., 1999] and will be defined by channel sample microcryst content at any point down-flow minus the source (at-vent) microphenocryst content that was grown prior to eruption.
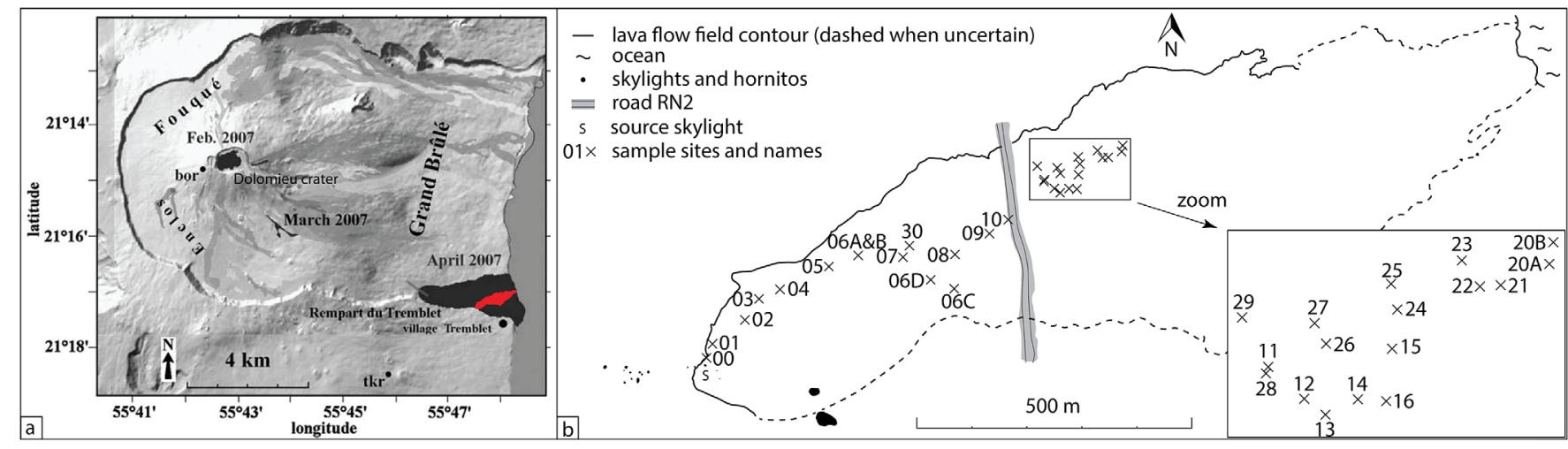

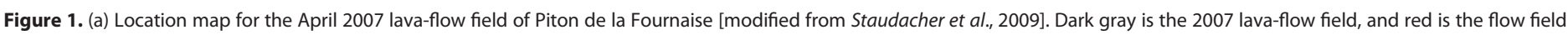
of the skylight vent(s). (b) The skylight vent(s) lava-flow field with sample location and names (these are PF07-XX, where XX is the number given in this figure). 


\subsection{The April 2007 Eruption}

The first effusive event of 2007 occurred during 18-19 February. The eruption lasted $9 \mathrm{~h}$ and was characterized by fountains of aphyric basalt from a fracture on the floor of the Dolomieu crater. A volume of $0.4 \times$ $10^{6} \mathrm{~m}^{3}$ of lava was erupted largely into the Dolomieu (Figure 1) with a small lava flow being emplaced high on Dolomieu's east flank [Staudacher et al., 2008]. A second event began on 30 March from an eruptive fissure located on the SE flank of the Dolomieu cone, at $1900 \mathrm{~m}$ above sea level (asl) (Figure 1). This event lasted $10 \mathrm{~h}$ and emitted $10^{6} \mathrm{~m}^{3}$ of aphyric basalt [Staudacher et al., 2008].

The third eruptive event of 2007 began on 2 April at 10 h00 (all times are local: GMT +4 ) from a point just $300 \mathrm{~m}$ from the southern edge of the Enclos Fouqué caldera at $590 \mathrm{~m}$ asl [Staudacher et al., 2008]. Lava began to enter the ocean ( $3 \mathrm{~km}$ from the vent) $11.5 \mathrm{~h}$ after the beginning of the eruption [Staudacher et al., 2009], with channel-fed flows of 'a'a developing which cut the island belt road (the RN2, $2 \mathrm{~km}$ from the vent) at $15 \mathrm{~h} 15$ [Staudacher et al., 2008]. Eruption intensity reached a maximum on 6 April when lava fountains reached $200 \mathrm{~m}$ in height (Figure 2a), effusion rates peaked at $200 \mathrm{~m}^{3} \mathrm{~s}^{-1}$ [Michon et al., 2007, 2009], and channel-fed lava flow extended to the ocean (Figure $2 b$ ).

After 14 April, a lava tube formed down the southern margin of the flow field close to the caldera wall. A line of skylights marking the line of the tube can, today, be observed down the southern margin of the flow field. One of these skylights became a secondary vent that emplaced a lava-flow field of braided channelfed 'a'a on top of earlier flows (Figure 2c). This vent is hereafter termed the skylight vent (Figure 2d). Activity continued in this style until $20 \mathrm{~h} 00$ on 1 May, when the eruption ended [Michon et al., 2009; Staudacher et al., 2009].

The April 2007 eruption emplaced oceanite lava flows with olivine contents ranging from 25 to $40 \%$ [Villemant et al., 2009]. Volumetrically the eruption was the largest historical eruption of PdF, with a subaerial lava
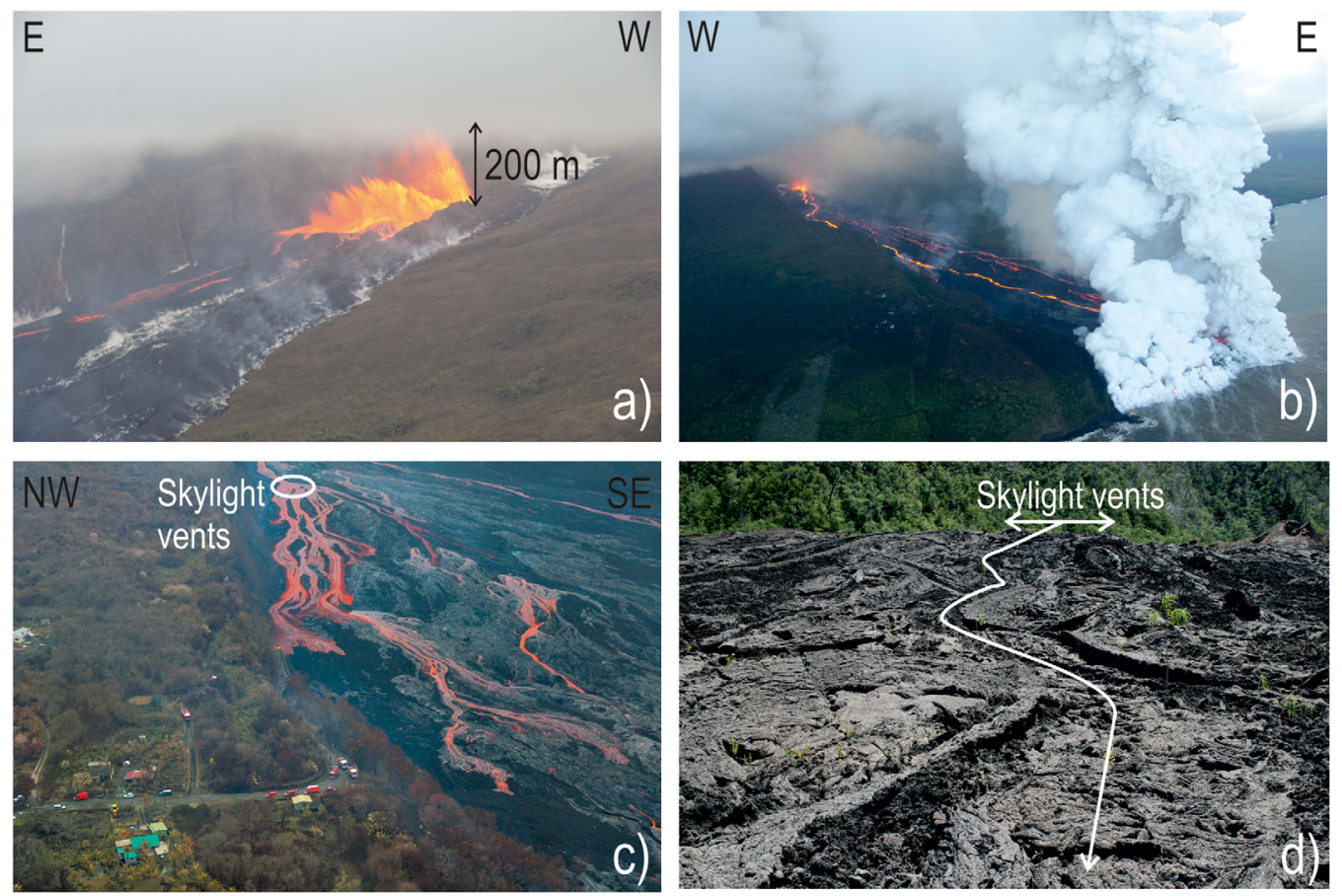

Figure 2. (a) Vent area, fountains and channel outlet on 7 April 2007 (at 15h45). Fountains are $200 \mathrm{~m}$ high. View is to the south with the Enclos Fouqué caldera wall in the background (photo: N. Villeneuve). (b) Southern portion of the lava-flow field on 5 April 2007 showing the entire $3 \mathrm{~km}$-length of channel-fed flow to the ocean. View is to the NW with the white houses of the village of Le Tremblet apparent in the foreground (Photo: N. Villeneuve). (c) Braided lava flow from the skylight vent on 26 April 2007 (photo: S. Gélabert, used with permission). View is to the west and the last houses, before the RN2 turns west and descends the caldera wall, of Le Tremblet are apparent in the foreground. (d) Up-flow view toward the skylight vent (hidden from view, but on the horizon, center) showing the proximal section of braided pahoehoe channels. Distance to skylight vent is $140 \mathrm{~m}$, channel in foreground is $7 \mathrm{~m}$ wide with $30 \mathrm{~cm}$ high, overhanging levees. A hornito that formed over one of the skylights is apparent on the horizon at the right (photo: A. Harris). 
volume of 110-140 $\times 10^{6} \mathrm{~m}^{3}$ and a nearshore submarine volume of $90 \times 10^{6} \mathrm{~m}^{3}$ [Bachèlery et al., 2010], the 29.6 day duration giving a mean output rate $84 \pm 6 \mathrm{~m}^{3} \mathrm{~s}^{-1}$. The final 16 days of effusion from the skylight vent built a rootless shield of largely channel-fed 'a'a on the south-eastern side of the flow field with a thickness of $50 \mathrm{~m}$ [Staudacher et al., 2009]. It is this portion of the lava-flow field on which we focus (Figure 2d).

\section{Methodology}

A map of the lava-flow field was produced using high-spatial resolution photographs taken from an airplane by one of us (NV) in 2011. To georeference and mosaic these photographs, we used a single, lower spatial resolution air photograph taken in 2008 of the whole area and used this to map all features that were large enough to be resolved. These included: the margin of the lava-flow field, skylights, levées, flow fronts and topographic structures. In addition, high-spatial resolution (mm-to- $\mathrm{cm})$ terrain models and orthophotographs were prepared for one section across the proximal portion of the channel, and four sections across the medial-distal portion of a single channel system using digital images obtained using a pole-mounted Canon EOS camera. These data were used to generate channel cross sections at each location.

Sampling, and channel + levee dimensional measurements, was then completed approximately every $60 \mathrm{~m}$ down the first $500 \mathrm{~m}$ (channelized segment) of two well-exposed L\&B systems identified within the flow field, and then every $10 \mathrm{~m}$ across the dispersed flow segment to the flow front (Figure 1). Sampling was conducted at locations where the lava was glassy. Glassy crusts would have been quenched fast enough so as to lock in their original texture [Riker et al., 2009; Soule et al., 2004; Robert et al., 2014]. That is, there was no postemplacement crystallization or vesicle reorganization, so that we can use these samples to understand the emplacement conditions of the lava. At each sample location, measurements of levée and channel dimensions were made using tape measure and compass-clinometer, as well as using hand-held and kinematic GPS. This allowed us to draw up morphological cross-section profiles and scaled sketch maps at each sampling location. All field measurements are given in supporting information Table A1 of Appendix A.

In addition, for samples PF07-06 to PF07-09, we were able to follow a man-made drainage ditch for $290 \mathrm{~m}$. This began $320 \mathrm{~m}$ from the skylight vent and cut tangentially, unit by unit, downward through the upper $30 \mathrm{~m}$ of the flow sequence, giving outcrop exposure of the flow interior, as well as the surface and basal breccia, for each unit. A north-south kinematic GPS profile was also completed across the entire flow field at this location to define the horizontal distribution, and widths, of all units comprising the upper surface of the field.

In the zone of transitional flow zone, the units were sufficiently well organized and defined so as to be able to follow two separate units (hereafter the North Channel and the South Channel). These were fed by a braided channel zone, where we followed the main stream feeding each channel back up to the skylight vent. We also sampled five flow fronts at approximately the same elevation as the flow fronts of the North and South Channels.

\subsection{Defining System Segments}

Following Lipman and Banks [1987], we define the transitional channel as zones where lava is flowing just below-bank (i.e., the channel is more-or-less brim-full). In such zones, a central flowing zone is separated from stagnant "lenses and ridges" of "slowly deforming" lava by flow-parallel shear-zones [Lipman and Banks, 1987, pp. 1534-1535]. It is in these marginal zones where the levees are beginning to form, so they have a simple morphology, being that of the initial or rubble levees of Sparks et al. [1976]. The transitional channel of Lipman and Banks 1987] was also characterized by "blocky" 'a'a. Clasts comprising such "distal 'a'a" [Rowland and Walker, 1987] have been modified by abrasion during passage down the channel system so that they have "coarse grain size and subangular forms mixed with clinkery 'a'â to form a heterogeneous rubble" [Harris et al., 2017]. Instead, the stable channel has flow levels well below-bank, with a narrow flowing stream flanked by broad, stable, nondeforming levees [Lipman and Banks, 1987]. Levees are mature and thus more complex, being compound levees resulting from construction during multiple overflow events [Sparks et al., 1976] which begin to bury the initial levees [Robert et al., 2014]. Lava in this part of the L\&B system is typically slaby pahoehoe or slaby 'a'a, with 'a'a characterized by loose spinoise clasts that have not 
yet undergone abrasion or "cauliflower lava" where spinoise 'a'a clasts are still rooted to the flow core [Kilburn and Guest, 1993]. This is proximal 'a'a [Rowland and Walker, 1987; Harris et al., 2017], where overflow levees can be of smoothed-surfaced pahoehoe [Robert et al., 2014].

\subsection{Geothermometer}

We set up a geothermometer for PdF using the results of experiments performed by Villeneuve [2000] on four lava samples taken from PdF lava-flow fields: an oceanite (from 1977), two aphyric basalts (from 1983 and 1998), and an olivine basalt (from 1986). Each sample was heated to six different temperatures (1100, $1125,1150,1167.5,1175$, and $1200^{\circ} \mathrm{C}$ ) in a one-atmosphere furnace under controlled oxygen fugacity conditions. As observed for Hawaiian lavas [e.g., Helz and Thornber, 1987], we found a linear relationship between temperature $(\mathrm{T})$ and $\mathrm{MgO}$ content of olivine-saturated glasses $\left(r^{2}=0.98\right)$ :

$$
T\left({ }^{\circ} \mathrm{C}\right)=26.253 \times \mathrm{MgO}(\text { wt \% })+993.1
$$

With this relation, we can now use glass chemistry analyses to calculate emplacement temperatures.

\subsubsection{Chemical Analyses}

Sample bulk chemistry was obtained from ICP-AES measurements. Three samples were analyzed: one close to the vent, one in the middle of the channel system, and one from the flow front (Table 1). Glass chemistry was obtained from electron microprobe analysis of samples selected on the basis of no oxidization, alteration, or presence of sulphur deposits. Only the upper part of the crust, in contact with the air (where the rock is very glassy) was selected. When a sample is air quenched, some rapid crystal growth can occur, modifying the composition of the glass immediately surrounding the crystals. To avoid this effect, glass measurements were carried out at a distance of at least $20 \mu \mathrm{m}$ from any crystal using a beam diameter of $10 \mu \mathrm{m}$. For each sample, between seven and 12 (typically eight) measurements were completed, as summarized in Table 2. We did not use measurements with an oxide total lower than $98 \%$, or higher than $102 \%$, and calculated the olivine/liquid $\mathrm{Fe}^{2+} / \mathrm{Mg}$ exchange coefficient $\left(\mathrm{K}_{\mathrm{D}}\right)$ for each glass measurement using an estimated oxygen fugacity so as to obtain the relative proportions of $\mathrm{Fe}^{2+}$ and $\mathrm{Fe}^{3+}$ (Table 3). Measurements with a low $\mathrm{K}_{\mathrm{D}}$ compared to the average (0.3) will be unreliable because they probably correspond to glass that has been depleted in magnesium due to rapid growth of neighboring crystals during quench. Temperatures derived following these analyses and rules are given in Table 4.

\subsection{Density and Vesicularity}

To measure lava bulk density, the method developed by Shea et al. [2010] was applied. Because the 2007 lava is rich in dense olivine macrocrysts, the measured DRE density will be strongly affected by, and will change if, the olivine content changes. Thus, we completed eight DRE density measurements at different distances from the vent. Lava DRE density usually refers to the density of the most common melt, so we do not want to take into account the macrocrysts that represent the withdrawal of the shallow mushes that are erupted only during the most energetic phases of PdF eruptions [Di Muro et al., 2014]. Thus, we need to

\begin{tabular}{|c|c|c|c|c|c|c|c|}
\hline \multirow{3}{*}{$\begin{array}{l}\text { Sample Name } \\
\text { Distance From } \\
\text { the Vent }(\mathrm{m})\end{array}$} & \multicolumn{2}{|c|}{ PF07-01 } & \multicolumn{2}{|c|}{ PF07-07 } & \multicolumn{2}{|c|}{ PF07-15 } & \multirow[b]{3}{*}{ Error $(1 \sigma)$} \\
\hline & \multicolumn{2}{|c|}{40} & \multicolumn{2}{|c|}{405} & \multicolumn{2}{|c|}{775} & \\
\hline & & wt $\%$ & Error $(1 \sigma)$ & wt \% & Error $(1 \sigma)$ & wt $\%$ & \\
\hline $\mathrm{SiO}_{2}$ & 43.5 & 0.3 & 42.7 & 0.3 & 42.6 & 0.3 & \\
\hline $\mathrm{Al}_{2} \mathrm{O}_{3}$ & 7.05 & 0.21 & 6.14 & 0.18 & 5.84 & 0.17 & \\
\hline $\mathrm{Fe}_{2} \mathrm{O}_{3}$ & 14.38 & 0.07 & 14.62 & 0.07 & 14.76 & 0.07 & \\
\hline $\mathrm{MgO}$ & 26.15 & 0.09 & 28.68 & 0.10 & 29.66 & 0.10 & \\
\hline $\mathrm{CaO}$ & 5.62 & 0.07 & 4.92 & 0.06 & 4.73 & 0.05 & \\
\hline $\mathrm{Na}_{2} \mathrm{O}$ & 1.235 & 0.022 & 1.098 & 0.019 & 1.025 & 0.018 & \\
\hline $\mathrm{K}_{2} \mathrm{O}$ & 0.354 & 0.020 & 0.282 & 0.016 & 0.283 & 0.016 & \\
\hline $\mathrm{TiO}_{2}$ & 1.365 & 0.018 & 1.185 & 0.015 & 1.131 & 0.015 & \\
\hline $\mathrm{MnO}$ & 0.1835 & 0.0015 & 0.1864 & 0.0015 & 0.1883 & 0.0015 & \\
\hline $\mathrm{P}_{2} \mathrm{O}_{5}$ & 0.151 & 0.007 & 0.139 & 0.007 & 0.144 & 0.007 & \\
\hline $\mathrm{Ba}$ & 0.00852 & 0.00023 & 0.00775 & 0.00021 & 0.00775 & 0.00021 & \\
\hline $\mathrm{Sr}$ & 0.0168 & 0.0004 & 0.0144 & 0.0004 & 0.0139 & 0.0004 & \\
\hline Total \% & 99.70 & & 99.54 & & 99.91 & & \\
\hline
\end{tabular}




\begin{tabular}{|c|c|c|c|c|c|c|c|c|c|c|c|c|c|c|c|c|c|c|c|c|c|c|}
\hline \multirow[b]{2}{*}{ Sam. } & \multirow[b]{2}{*}{ No. } & \multicolumn{2}{|c|}{$\mathrm{SiO}_{2}$} & \multicolumn{2}{|c|}{$\mathrm{TiO}_{2}$} & \multicolumn{2}{|c|}{$\mathrm{Al}_{2} \mathrm{O}_{3}$} & \multicolumn{2}{|c|}{$\mathrm{Cr}_{2} \mathrm{O}_{3}$} & \multicolumn{2}{|c|}{$\mathrm{FeO}$} & \multicolumn{2}{|c|}{$\mathrm{MnO}$} & \multicolumn{2}{|c|}{$\mathrm{MgO}$} & \multicolumn{2}{|c|}{$\mathrm{CaO}$} & \multicolumn{2}{|c|}{$\mathrm{Na}_{2} \mathrm{O}$} & \multicolumn{2}{|c|}{$\mathrm{K}_{2} \mathrm{O}$} & \multirow[b]{2}{*}{ Total } \\
\hline & & wt \% & $\sigma$ & wt \% & $\sigma$ & wt \% & $\sigma$ & wt \% & $\sigma$ & wt \% & $\sigma$ & wt \% & $\sigma$ & wt $\%$ & $\sigma$ & wt \% & $\sigma$ & wt $\%$ & $\sigma$ & wt \% & $\sigma$ & \\
\hline 1 & 7 & 49.51 & 0.31 & 2.79 & 0.06 & 14.01 & 0.18 & 0.04 & 0.04 & 10.41 & 0.37 & 0.15 & 0.09 & 6.61 & 0.05 & 11.44 & 0.16 & 2.65 & 0.17 & 0.73 & 0.02 & 98.46 \\
\hline $11 \mathrm{~b}$ & 12 & 49.77 & 0.29 & 2.86 & 0.06 & 14.26 & 0.17 & 0.02 & 0.04 & 10.71 & 0.36 & 0.15 & 0.09 & 6.20 & 0.04 & 11.21 & 0.15 & 2.71 & 0.16 & 0.78 & 0.02 & 96.72 \\
\hline 7 & 8 & 49.67 & 0.30 & 2.95 & 0.06 & 13.70 & 0.17 & 0.05 & 0.04 & 10.97 & 0.36 & 0.18 & 0.09 & 6.49 & 0.04 & 11.31 & 0.15 & 2.67 & 0.16 & 0.79 & 0.02 & 98.78 \\
\hline 5 & 8 & 49.61 & 0.30 & 2.86 & 0.06 & 13.97 & 0.17 & 0.03 & 0.04 & 10.52 & 0.36 & 0.16 & 0.09 & 6.54 & 0.04 & 11.41 & 0.15 & 2.68 & 0.16 & 0.76 & 0.02 & 98.46 \\
\hline 3 & 8 & 49.87 & 0.30 & 2.83 & 0.06 & 14.15 & 0.17 & 0.05 & 0.04 & 10.41 & 0.35 & 0.16 & 0.09 & 6.58 & 0.04 & 11.41 & 0.15 & 2.70 & 0.16 & 0.74 & 0.02 & 98.88 \\
\hline 15 & 11 & 49.69 & 0.32 & 3.21 & 0.09 & 13.37 & 0.17 & 0.03 & 0.04 & 11.75 & 0.36 & 0.19 & 0.09 & 6.09 & 0.04 & 10.81 & 0.18 & 2.76 & 0.17 & 0.87 & 0.03 & 98.56 \\
\hline 8 & 8 & 49.79 & 0.30 & 2.88 & 0.06 & 13.83 & 0.17 & 0.04 & 0.03 & 10.87 & 0.36 & 0.18 & 0.09 & 6.51 & 0.04 & 11.40 & 0.15 & 2.66 & 0.16 & 0.77 & 0.02 & 98.94 \\
\hline 13 & 7 & 49.59 & 0.30 & 3.29 & 0.09 & 13.47 & 0.17 & 0.00 & 0.03 & 12.49 & 0.36 & 0.15 & 0.09 & 5.91 & 0.04 & 10.55 & 0.18 & 2.39 & 0.17 & 0.88 & 0.03 & 98.73 \\
\hline 16 & 10 & 49.56 & 0.31 & 3.32 & 0.08 & 13.28 & 0.17 & 0.03 & 0.03 & 11.82 & 0.36 & 0.21 & 0.09 & 5.87 & 0.04 & 10.74 & 0.17 & 2.66 & 0.17 & 0.89 & 0.03 & 98.13 \\
\hline 2 & 8 & 49.71 & 0.30 & 2.78 & 0.06 & 14.14 & 0.17 & 0.05 & 0.04 & 10.52 & 0.36 & 0.17 & 0.09 & 6.64 & 0.04 & 11.44 & 0.15 & 2.61 & 0.16 & 0.74 & 0.02 & 98.69 \\
\hline 4 & 8 & 49.68 & 0.30 & 2.84 & 0.06 & 14.01 & 0.17 & 0.04 & 0.04 & 10.59 & 0.36 & 0.16 & 0.09 & 6.56 & 0.04 & 11.44 & 0.15 & 2.64 & 0.16 & 0.74 & 0.02 & 98.71 \\
\hline $20 \mathrm{~b}$ & 8 & 49.68 & 0.37 & 2.87 & 0.15 & 13.88 & 0.20 & 0.05 & 0.06 & 10.88 & 0.27 & 0.17 & 0.07 & 6.40 & 0.05 & 11.27 & 0.32 & 2.27 & 0.18 & 0.79 & 0.05 & 98.21 \\
\hline 27 & 8 & 49.67 & 0.31 & 2.99 & 0.10 & 13.78 & 0.16 & 0.04 & 0.04 & 10.93 & 0.26 & 0.17 & 0.06 & 6.41 & 0.04 & 11.30 & 0.23 & 2.63 & 0.16 & 0.78 & 0.04 & 98.71 \\
\hline 28 & 8 & 49.57 & 0.32 & 2.78 & 0.11 & 14.17 & 0.17 & 0.06 & 0.05 & 10.46 & 0.24 & 0.15 & 0.06 & 6.59 & 0.04 & 11.47 & 0.26 & 2.63 & 0.16 & 0.71 & 0.04 & 98.61 \\
\hline 29 & 9 & 49.71 & 0.32 & 2.86 & 0.12 & 14.22 & 0.17 & 0.06 & 0.05 & 10.57 & 0.23 & 0.18 & 0.06 & 6.38 & 0.04 & 11.51 & 0.26 & 2.43 & 0.15 & 0.72 & 0.04 & 98.64 \\
\hline $11 a$ & 7 & 49.58 & 0.33 & 2.85 & 0.14 & 13.96 & 0.17 & 0.04 & 0.05 & 10.81 & 0.17 & 0.18 & 0.04 & 6.33 & 0.04 & 11.44 & 0.32 & 2.48 & 0.15 & 0.76 & 0.05 & 98.26 \\
\hline 14 & 7 & 49.68 & 0.34 & 3.15 & 0.16 & 13.37 & 0.17 & 0.02 & 0.05 & 11.21 & 0.18 & 0.17 & 0.04 & 6.06 & 0.04 & 11.31 & 0.33 & 2.64 & 0.16 & 0.82 & 0.05 & 98.23 \\
\hline 24 & 8 & 49.47 & 0.37 & 2.88 & 0.17 & 13.99 & 0.20 & 0.03 & 0.29 & 10.82 & 0.19 & 0.16 & 0.05 & 6.15 & 0.05 & 11.57 & 0.37 & 2.67 & 0.18 & 0.77 & 0.06 & 98.44 \\
\hline 26 & 8 & 49.55 & 0.33 & 2.71 & 0.14 & 14.13 & 0.17 & 0.04 & 0.06 & 10.46 & 0.16 & 0.17 & 0.04 & 6.58 & 0.04 & 11.57 & 0.32 & 2.59 & 0.15 & 0.73 & 0.05 & 98.54 \\
\hline 22 & 8 & 49.50 & 0.33 & 2.78 & 0.14 & 14.09 & 0.17 & 0.05 & 0.05 & 10.64 & 0.17 & 0.16 & 0.04 & 6.50 & 0.04 & 11.54 & 0.32 & 2.53 & 0.15 & 0.73 & 0.05 & 98.43 \\
\hline
\end{tabular}

${ }^{a}$ First two columns give the sample label ("sam") and number of measurements made ("No."), where oxide weight percent, standard deviations, and totals are averages of all measurements made on each sample.

define two DRE densities: (i) the measured density which takes into account the macrocrysts, which we term an "apparent DRE density" ( $\left.\rho_{D R E, a}\right)$ and (ii) the initial DRE density of the melt without macrocrysts, which we term the "melt DRE density" $\left(\rho_{D R E, m}\right)$. The latter cannot be measured with our samples, but we can assume that it is the same for all lavas of Piton de la Fournaise, so we use the value of $2970 \pm 300 \mathrm{~kg}$ $\mathrm{m}^{-3}$ obtained for the 2010 lava flow by Harris et al. [2016]. To obtain vesicularity, we then used these dense rock values in the Archimedes-based conversion of Houghton and Wilson [1989] (see: On Floating Bodies, Book I, Proposition 7: In Heath [1897, pp. 253-262]).

\subsection{Crystallinity}

The presence of olivine macrocrysts will affect the Dense Rock Equivalent (DRE) density of the lava, where the apparent DRE density of the 2007 oceanite will be higher than the usual DRE density due to the preponderance of macrocrysts. This difference can be used as a method to estimate macrocryst content $\left(\Phi_{\text {macro }}\right)$ following:

Table 3. Oxygen Fugacity $\left(\mathrm{fO}_{2}\right.$ ) and $\mathrm{K}_{\mathrm{D}}$ Values for the Analyzed Samples; $\mathrm{Fe}^{3+} / \mathrm{Fe}^{2+}$ and $\mathrm{Fe}^{3+} / \mathrm{Fe}_{\text {tot }}$ Ratios Were Calculated Using the Equations of Kress and Carmichael [1991]

\begin{tabular}{llccc} 
Sample & $\log \left(\mathrm{fO}_{2}\right)$ & $\mathrm{Fe}^{3+} / \mathrm{Fe}^{2+}$ & $\mathrm{Fe}^{3+} / \mathrm{Fe}_{\text {tot }}$ & $\mathrm{K}_{\mathrm{D}}$ \\
\hline 1 & -8.12 & 0.24 & 0.19 & 0.34 \\
$11 \mathrm{~b}$ & -8.24 & 0.24 & 0.19 & 0.30 \\
7 & -8.15 & 0.24 & 0.19 & 0.30 \\
5 & -8.14 & 0.24 & 0.19 & 0.32 \\
3 & -8.13 & 0.24 & 0.19 & 0.33 \\
15 & -8.30 & 0.24 & 0.19 & 0.30 \\
8 & -8.15 & 0.24 & 0.19 & 0.32 \\
13 & -8.34 & 0.23 & 0.18 & 0.26 \\
16 & -8.34 & 0.24 & 0.19 & 0.28 \\
2 & -8.11 & 0.24 & 0.19 & 0.35 \\
4 & -8.13 & 0.24 & 0.19 & 0.32 \\
$20 \mathrm{~b}$ & -8.18 & 0.23 & 0.19 & 0.30 \\
27 & -8.18 & 0.24 & 0.19 & 0.28 \\
28 & -8.12 & 0.24 & 0.19 & 0.33 \\
29 & -8.19 & 0.24 & 0.19 & 0.35 \\
$11 \mathrm{a}$ & -8.20 & 0.24 & 0.19 & 0.30 \\
14 & -8.29 & 0.24 & 0.19 & 0.29 \\
24 & -8.26 & 0.24 & 0.20 & 0.27 \\
26 & -8.13 & 0.24 & 0.19 & 0.34 \\
22 & -8.15 & 0.24 & 0.19 & 0.31 \\
\hline
\end{tabular}

$$
\Phi_{\text {macro }}=\frac{\rho_{D R E, a}-\rho_{D R E, m}}{\rho_{\text {olivine }}-\rho_{D R E, m}}
$$

Here the density of olivine macrocrysts ( $\left.\rho_{\text {olivine }}\right)$ have been calculated using their composition, and the densities of end-members forsterite $(3270 \mathrm{~kg}$ $\mathrm{m}^{-3}$ ) and fayalite $\left(4390 \mathrm{~kg} \mathrm{~m}^{-3}\right)$ [Fisher and Medaris 1969], and is approximately $3450 \mathrm{~kg} \mathrm{~m}^{-3}$.

We applied the FOAMS software of Shea et al. [2010] to obtain the 2-D percentage of crystals and qualitative crystal size distribution (CSD). The CSD is qualitative, in the sense that we have not applied the shape corrections proposed by Higgins [2000], because we were only interested in identifying the main size-based populations for the whole crystals (see also Gurioli et al. [2014]; and for quantitative CSD at PdF see Di Muro et al. [2014]). We analyzed two samples: one near the vent and one at the flow 


\begin{tabular}{|c|c|c|c|c|}
\hline Sample & Distance (m) & $\mathrm{T}\left({ }^{\circ} \mathrm{C}\right)$ & Error $(1 \sigma)$ & $\begin{array}{c}\text { Location in System } \\
\text { and } K_{D} \text { Notes }\end{array}$ \\
\hline PF07-01 & 40 & 1166.6 & 0.6 & Zones A\&B \\
\hline PF07-02 & 115 & 1167.5 & 0.6 & Zones A\&B \\
\hline PF07-03 & 160 & 1165.7 & 2.1 & Zones A\&B \\
\hline PF07-04 & 205 & 1165.2 & 0.8 & Zones A\&B \\
\hline PF07-05 & 295 & 1164.8 & 1.1 & Zones A\&B \\
\hline PF07-07 & 405 & 1164.6 & 2 & Zones A\&B \\
\hline PF07-08 & 475 & 1164.0 & 1.2 & Zones A\&B \\
\hline PF07-11a & 705 & 1159.2 & 1.6 & Zone C, S-Channel $\left(K_{D}<0.3\right)$ \\
\hline PF07-11b & 705 & 1155.8 & 3 & Zone C, S-Channel $\left(K_{D}<0.3\right)$ \\
\hline PF07-13 & 735 & 1147.7 & 0.7 & Zone C, S-Channel $\mathrm{K}_{\mathrm{D}}<0.3$ ) \\
\hline PF07-14 & 745 & 1152.2 & 2.7 & Zone C, S-Channel $\left(K_{D}<0.3\right)$ \\
\hline PF07-16 & 770 & 1147.9 & 1.7 & Zone D, S-Channel $\left(K_{D}<0.3\right)$ \\
\hline PF07-15 & 775 & 1151.5 & 2.7 & Zone D, S-Channel \\
\hline PF07-29 & 705 & 1160.5 & 2.5 & Zone C, N-Channel \\
\hline PF07-28 & 705 & 1166.1 & 3 & Zone C, N-Channel \\
\hline PF07-27 & 745 & 1161.4 & 1.5 & Zone C, N-Channel \\
\hline PF07-26 & 745 & 1165.8 & 1.5 & Zone C, N-Channel \\
\hline PF07-24 & 820 & 1154.4 & 5 & Zone C, N-Channel $\left(K_{D}<0.3\right)$ \\
\hline PF07-22 & 830 & 1163.7 & 1.3 & Zone C, N-Channel \\
\hline PF07-20b & 865 & 1161.2 & 1.1 & Zone D, N-Channel \\
\hline
\end{tabular}

front (samples PF07-01 and PF07-15), and all textural measurements for all samples are summarized in supporting information Table A2 of Appendix A.

Microcryst contents were also obtained from microprobe analyses, for which oxygen fugacity's are given in Table 3. To calculate the groundmass composition we used the megaolivine content, derived from the apparent DRE density, in

$X_{i, \text { groundmass }}=\frac{X_{i, \text { bulk }}-\Phi_{\text {macrocryst }} X_{i, \text { macrocryst }}}{1-\Phi_{\text {macrocryst }}}$

Here $X_{i, p h a s e}$ is the concentration of element $i$ in each phase, so that the mass balance becomes

$$
X_{i, \text { groundmass }}=\sum_{\text {phase }}\left(\Phi_{\text {phase }} X_{i, \text { phase }}\right)
$$

The phases taken into account were glass, microolivine, pyroxene, and plagioclase; and the chemical elements used were $\mathrm{SiO}_{2}, \mathrm{TiO}_{2}, \mathrm{Al}_{2} \mathrm{O}_{3}, \mathrm{FeO}, \mathrm{MnO}, \mathrm{MgO}, \mathrm{CaO}, \mathrm{Na}_{2} \mathrm{O}$, and $\mathrm{K}_{2} \mathrm{O}$.

\subsection{Rheology and FLOWGO Modeling}

To estimate the yield strength of the lava $\left(\tau_{0}\right)$, we followed Harris and Rowland [2001] who combined the temperature dependent model of Dragoni [1989] with the crystal-dependent model of Ryerson et al. [1988] to estimate $\tau_{0}$ from

$$
\tau_{0}=6500 \times \Phi_{x l, t o t}^{2.85}+b \times \exp ^{c\left(T_{\mathrm{e}}-T_{\text {core }}\right)-1}
$$

Here $T_{e}$ is the eruption temperature, $T_{\text {core }}$ is the flow core temperature, and $b$ and $c$ are constants with values of $10^{-2} \mathrm{~Pa}$ and $0.08 \mathrm{~K}^{-1}$, respectively [Dragoni, 1989]. We also estimated yield strength from flow front thickness following Hulme [1974].

Viscosity of the fluid phase $\left(\eta_{f}\right)$ was obtained as a function of temperature $(T)$ following the relation of Villeneuve et al. [2008] for PdF lavas:

$$
\eta_{f}=10^{-4.52+5558 /(T-582.9)}
$$

Now mixture viscosity can be obtained at each sample site following the three-phase model of Phan-Thien and Pham [1997]. Depending on the relative size of crystals $\left(\Phi_{x l, t o t}\right)$ and vesicles $\left(\Phi_{b}\right)$, three equations exist:

1. For crystals smaller than vesicles:

$$
\eta=\eta_{f}\left(1-\frac{\Phi_{x l, t o t}}{1-\Phi_{b}}\right)^{-\frac{5}{2}}\left(1-\Phi_{b}\right)^{-1}
$$

2. For crystals and vesicles with the same size:

$$
\eta=\eta_{f}\left[1-\Phi_{x l, t o t}-\Phi_{b}\right]\left(-5 \Phi_{x, t \text { tot }}+2 \Phi_{b}\right) /\left(2\left(\Phi_{x x, \text { tot }}+\Phi_{b}\right)\right)
$$

3. For crystals larger than vesicles:

$$
\eta=\eta_{f}\left(1-\frac{\Phi_{b}}{1-\Phi_{x l, t o t}}\right)^{-1}\left(1-\Phi_{x l, t o t}\right)^{-\frac{5}{2}}
$$


In our samples, there are microcrysts that are smaller than vesicles and macrocrysts that are larger than vesicles, making the choice of the three-phase model difficult. Therefore, we used FLOWGO-based modeling to assess the best model through best fitting of FLOWGO control volume temperature and crystallinity with sample-based measurements.

\subsubsection{FLOWGO-Based Modeling}

FLOWGO is a one-dimensional thermorheological model that allows reconstruction of the one-dimensional (i.e., down-flow) thermal, textural, rheological, and dynamic evolution of a lava control volume as it moves down a channel [Harris and Rowland, 2001, 2015]. FLOWGO also assesses the maximum length that a channel-contained control volume can extend under cooling-limited conditions before freezing, while conserving volume by varying channel width. We thus used FLOWGO to assess if this channel-fed flow system was volume or cooling limited, while assessing best-fit with all down-flow temperature and crystallinity measurements for each viscosity relation. That is, if the modeled control volume runs further than reality, while fitting all control parameters, then it indicates that the lava did not stop for cooling and rheological reasons, instead flow stopped because supply was volume limited. To explore the potential effects of vesicle deformation and crystal content, we ran FLOWGO using the models of equation (7) along with two other models, for deformed and spherical vesicles respectively, from Llewellin and Manga [2005]. Also, following Mader et al. [2013], to consider the effects of crystal size and shape, as well as potential shear thinning effects and high (>50\%) crystallinities we used the relation of Maron and Pierce [1956] for particles with an aspect ratio of 1:4 [Mueller et al., 2010]. Finally, we applied the relation of Costa et al. [2009] to consider the effects of spherical and elongated (with an aspect ratio of 1:9) particles (as given in Cimarelli et al. [2011]).

\subsection{Velocity and Effusion Rate}

With bulk density, viscosity, and yield strength in hand, we can now estimate mean flow velocity $\left(v_{\text {mean }}\right)$ at each channel station following Moore [1987]:

$$
v_{\text {mean }}=\left(\frac{h 2 \rho_{\text {bulk }} g \sin \theta}{8 \eta}\right)\left(1-\frac{4 \tau_{0}}{3 \tau_{b}}+\frac{1}{3}\left(\frac{\tau_{0}}{\tau_{b}}\right)^{4}\right)
$$

in which $h$ is the flow thickness, $g$ is acceleration due to gravity, and $\theta$ is the underlying slope, and $\tau_{b}$ is basal shear stress which can be obtained from [Hulme, 1974]:

$$
\tau_{b}=h \rho_{\text {bulk }} g \sin \theta
$$

Now, effusion rate $\left(E_{r}\right)$ can be calculated using:

$$
E_{r}=h w v_{\text {mean }}
$$

in which $w$ is channel width. Velocity and effusion rate are both parameters that evolve with time [e.g., Wadge, 1981; Bailey et al., 2006; Harris et al., 2009], with velocity also changing in space, i.e., down-channel [e.g., Lipman and Banks, 1987; Harris and Rowland, 2001; Robert et al., 2014]. Thus, we calculate a minimum and a maximum likely flow velocity and effusion rate that would have fed the channel by solving (8) through (10) using the highest $\left(h_{\max }\right)$ and lowest $\left(h_{\min }\right)$ flow levels measured at each station. While $h_{\max }$ relates to brim full flow and will be associated with the highest flow rate, $h_{\min }$ will be the final (below-bank) flow level.

\section{Results}

The source was a $5.3 \mathrm{~m} \times 2.1 \mathrm{~m}$ skylight above a $14 \mathrm{~m}$ high tube with a $4 \mathrm{~m}$ thick roof (Figure 3a). Proximally, a $4.6 \mathrm{~m}$-wide master channel extended north east from the source. This channel forked into two branches after a distance of $40 \mathrm{~m}$, a point which marked the beginning of braided flow (Figure $4 \mathrm{~b}$ ). Repeated overflow had built a rootless shield around the skylight vent down which slopes were $11^{\circ}$. The base of the shield was marked by a break-in-slope, where slopes declined to $6^{\circ}$ at a distance of $250 \mathrm{~m} \mathrm{NE}$ of the skylight vent, meaning that the shield was around $50 \mathrm{~m}$ high; which is approximately the thickness of the flow field in this location [Staudacher et al., 2009]. Given this height and radius, and given the form of a dome, we estimate the shield bulk volume to be $0.48 \times 10^{6} \mathrm{~m}^{3}$. The braided channel system on the upper flanks of the shield included shallow $(0.8 \pm 0.4 \mathrm{~m}$ deep) pahoehoe channels (Figure 5$)$, with 'a'a and transitional pahoehoe forms being more common on the channel floor and as overflow units on the lower flanks. 

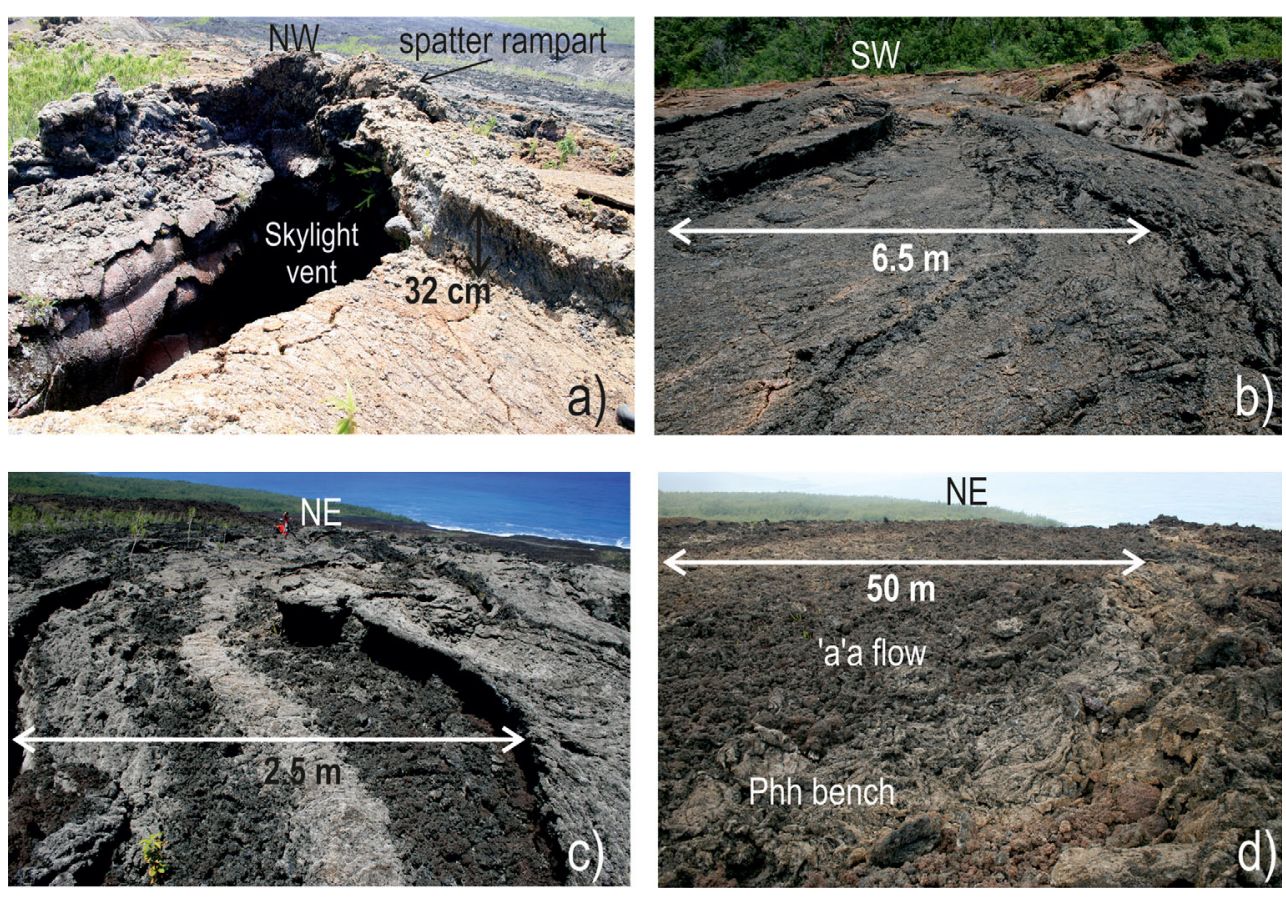

Figure 3. (a) Skylight vent and left bank of the outlet channel. Skylight is $2.1 \mathrm{~m}$ across, and overhanging rim of outlet channel is $32 \mathrm{~cm}$ high. Note: spatter and spatter rampart around the NW rim of the skylight. (b) Master channel below the skylight vent. Channel is $6.5 \mathrm{~m}$ wide and view is SW back-up toward the skylight vent. (c) View NE down a $2.5 \mathrm{~m}$-wide channel in zone A. (d) View NE down the N channel just below RN2. Here the channel is $50 \mathrm{~m}$ wide; the white altered zone marks the location of a bench inboard of the right bank levée.

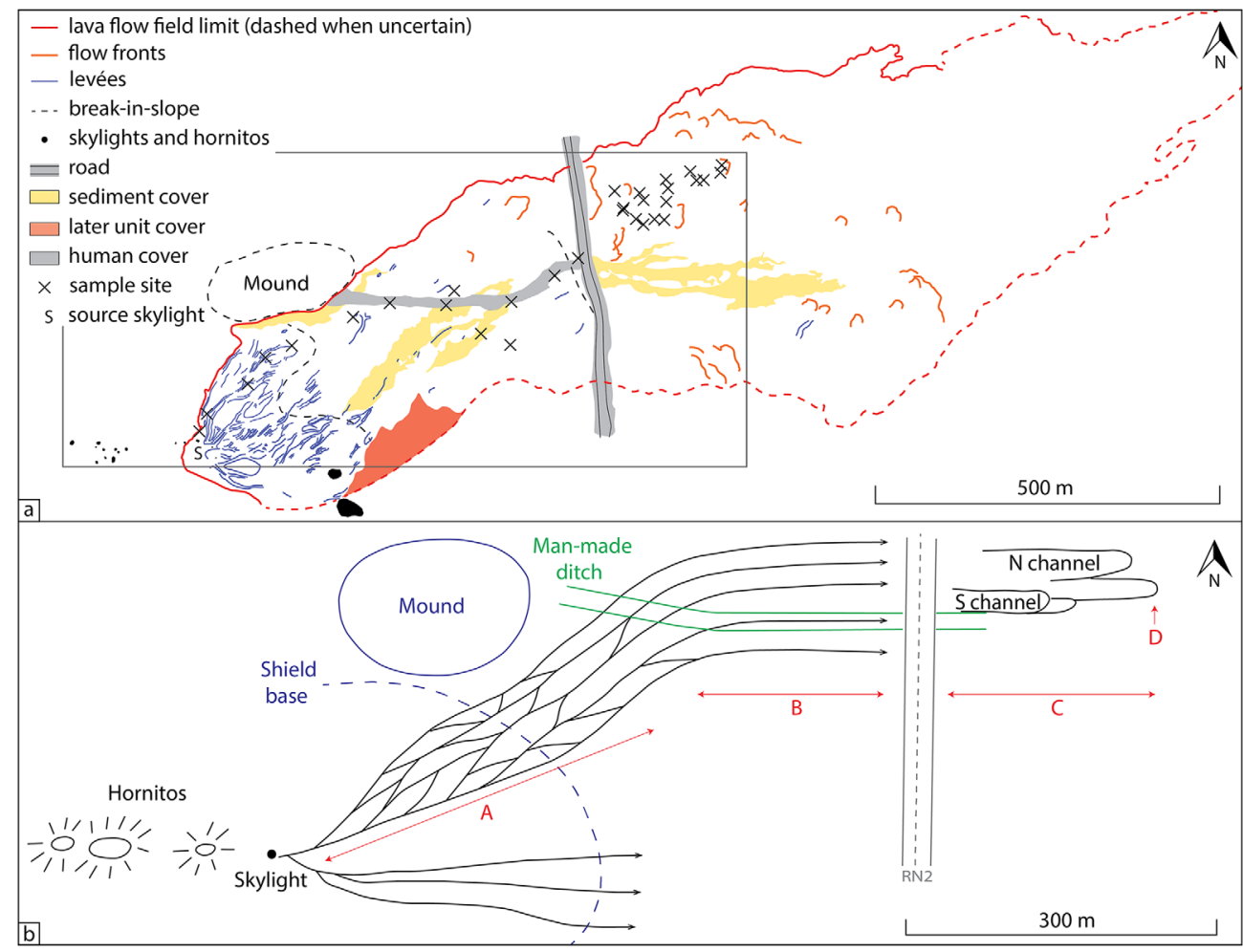

Figure 4. (a) Morphological and (b) schematic map of the lava-flow field fed by the skylight vent. Letters mark the four flow field zones: (A) braided, stable channel; (B) stable 'a'a channels; (C) broad, shear-zone defined channels; and (D) dispersed flow and flow front. In the case mapped, flow becomes focused into two streams: the north $(\mathrm{N})$ channel and the south $(\mathrm{S})$ channel. 


\section{QAGU Geochemistry, Geophysics, Geosystems}

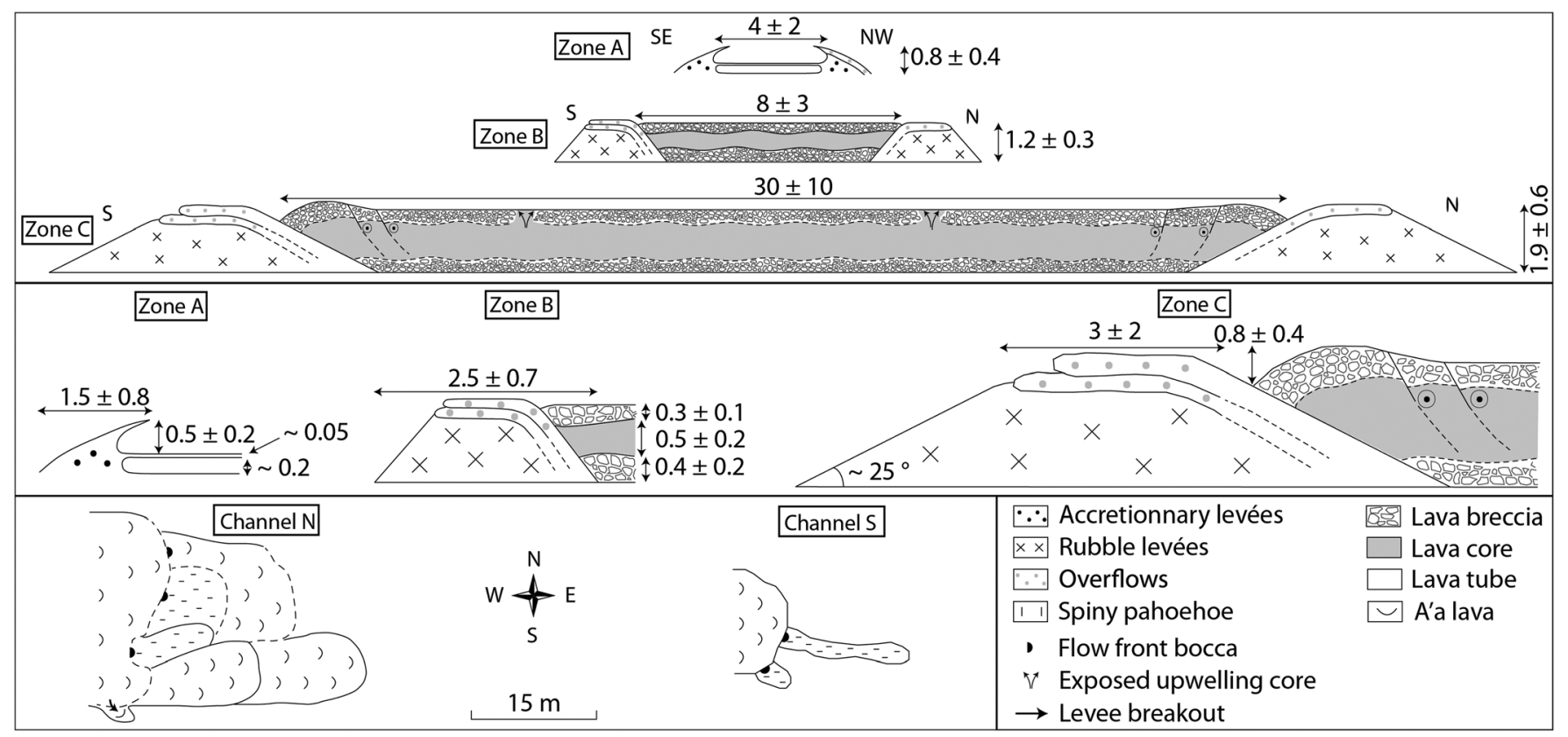

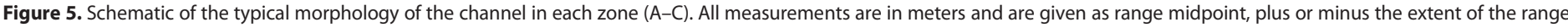
around that midpoint. The bottom part is a scaled sketch map of the lava fronts at the end of the north $(\mathrm{N})$ and south $(\mathrm{S})$ channels.

Beyond the base of the shield, the medial section of the flow system was composed of 'a'a lava, with sediment and anthropogenic cover around the road, RN2 (Figure 4). Across this section, units were of 'a'a with rubble levees defining near-brim-full and wide $(30 \pm 0.4 \mathrm{~m})$ channels (Figure 5). Flows comprising this zone were exposed in the man-made ditch that ran E-W to the RN2 (Figure 4). Here we found 15 'a'a units in vertical sequence with an average thickness of $1.2 \pm 0.3 \mathrm{~m}$ (range: $0.74-1.70 \mathrm{~m}$ ), underlain by a $13 \mathrm{~m}$ thick 'a'a unit with columnar joints with $6 \pm 1$ sides and long axes of $70 \pm 20 \mathrm{~cm}$. The north-south (across flow-field kinematic GPS profile that we made across the entire flow field revealed the area of lava fed by the skylight vent to be $290 \mathrm{~m}$ wide, with there being eight 'a'a channels located across this width. These eight channels had widths of between 10 and $70 \mathrm{~m}$, with the flow field sloping at $4.7^{\circ}$ to the south, i.e., upward toward the tube.

The distal section of the system, just below RN2, was composed of at least 33 flow fronts in a zone extending between 500 and $900 \mathrm{~m}$ from the source (Figure 4b). Beyond this point, the flow field narrowed and was composed of a smaller number of flow units (Figure 4a). We found a total of ten flow fronts along an east-west (down-flow field) transect between the end of the North Channel and the coast, this being a distance of $600 \mathrm{~m}$. At the coast, the flow field comprised broad 'a'a units, with thicknesses of 0.6-1.2 $\mathrm{m}$.

\subsection{Flow Zones}

Following the channelized lava-flow system of Lipman and Banks [1987], four down-system zones can be defined (Figure 4):

1. Zone A: a proximal segment of well-formed channels that run in and out of each other to form a braided channel system to the base of the rootless shield.

2. Zone B: an upper medial segment composed of stable 'a'a channels that are brim-full and fed by zone A.

3. Zone C: a lower medial segment of broad, shear-zone defined and brim-full channels.

4. Zone D: a distal segment of dispersed flow behind the flow front.

While zone A corresponds to the stable channel segment of Lipman and Banks [1987], zones B and C correspond to the transitional channel zone, and zone $D$ to the dispersed flow and flow front segments of the L\&B system. Unfortunately, the island belt road (RN2) was rebuilt at the transition between zones B and C, so that there is a lack of samples and measurements across this transition. The shape and cross-sectional structure of the channel and its levees does, though, increase at each of the four zone boundaries; with 
there being a marked increase in channel width, from $8 \pm 3$ to $30 \pm 10 \mathrm{~m}$ over a distance of just a few tens of meters between zones $B$ and $C$ (Figure 5).

\subsubsection{Zone A}

Channels are relatively narrow (2-6 $\mathrm{m}$ wide) in zone A (Figure 5) and comprise a complex system of anastomosing flow (Figure $2 \mathrm{~d}$ ). Levées are $0.8 \pm 0.4 \mathrm{~m}$ high and are composed of overhanging accretionary levees and smooth-surfaced pahoehoe overflow, both of which mantle the initial, pahoehoe and rubble levees (Figure $3 \mathrm{~b}$ ). The flow surface is typically $30-80 \mathrm{~cm}$ below the levee rim, and channel widths are 2-6 $\mathrm{m}$. Tubes, with head spaces of up to 20 and $5 \mathrm{~cm}$ thick pahoehoe roofs, can be found on the channel floor, which is of pahoehoe. With distance, channel form remains stable, but lava in the channel is increasingly composed of 'a'a, or is the form of a pahoeohoe plug zone bounded by 'a'a shear-zones (Figure 3c). The master channel just above the first bifurcation, $40 \mathrm{~m}$ from the skylight vent, is a $6.5 \mathrm{~m}$-wide pahoehoe channel emplaced on a flow field of slabby pahoehoe. The floor slopes gently downward from the north levée toward the channel center, so that the floor is $60 \mathrm{~cm}$ above the datum at the crest of the left-bank levee, and $20 \mathrm{~cm}$ above datum at the channel center. The channel floor and overflow levees are of smoothsurfaced, S-type pahoehoe sheet flow (Figure 3b).

\subsubsection{Zone B}

In zone B, broader (5-11 m wide) and higher (0.9-1.5 m) rubble levées contain near-bank full 'a'a (Figure 5). Levées are dominated by the initial, rubble construct, with minor accreted and overflow levées, with overflow typically just extending onto the crest of the initial, rubble levée, and not extending down the levée outer flank.

\subsubsection{Zone $C$}

Zone $C$ comprises wide (20-40 m) 'a'a channels bounded by broad ( $3 \pm 10 \mathrm{~m}$ wide) levees (Figure 5). Flow is 0.4-1.2 $\mathrm{m}$ below the levée rim, and the flow-levée boundary is usually marked by a line of shear expressed by a narrow gully at the contact between the flow and the levée (Figure 5). Levée morphology is similar to that of zone B, but inboard of the levées benches of static lava can be found forming nested leves. Inboard of the levees, these are bounded by flow-parallel shear-zones that separate the static, marginal

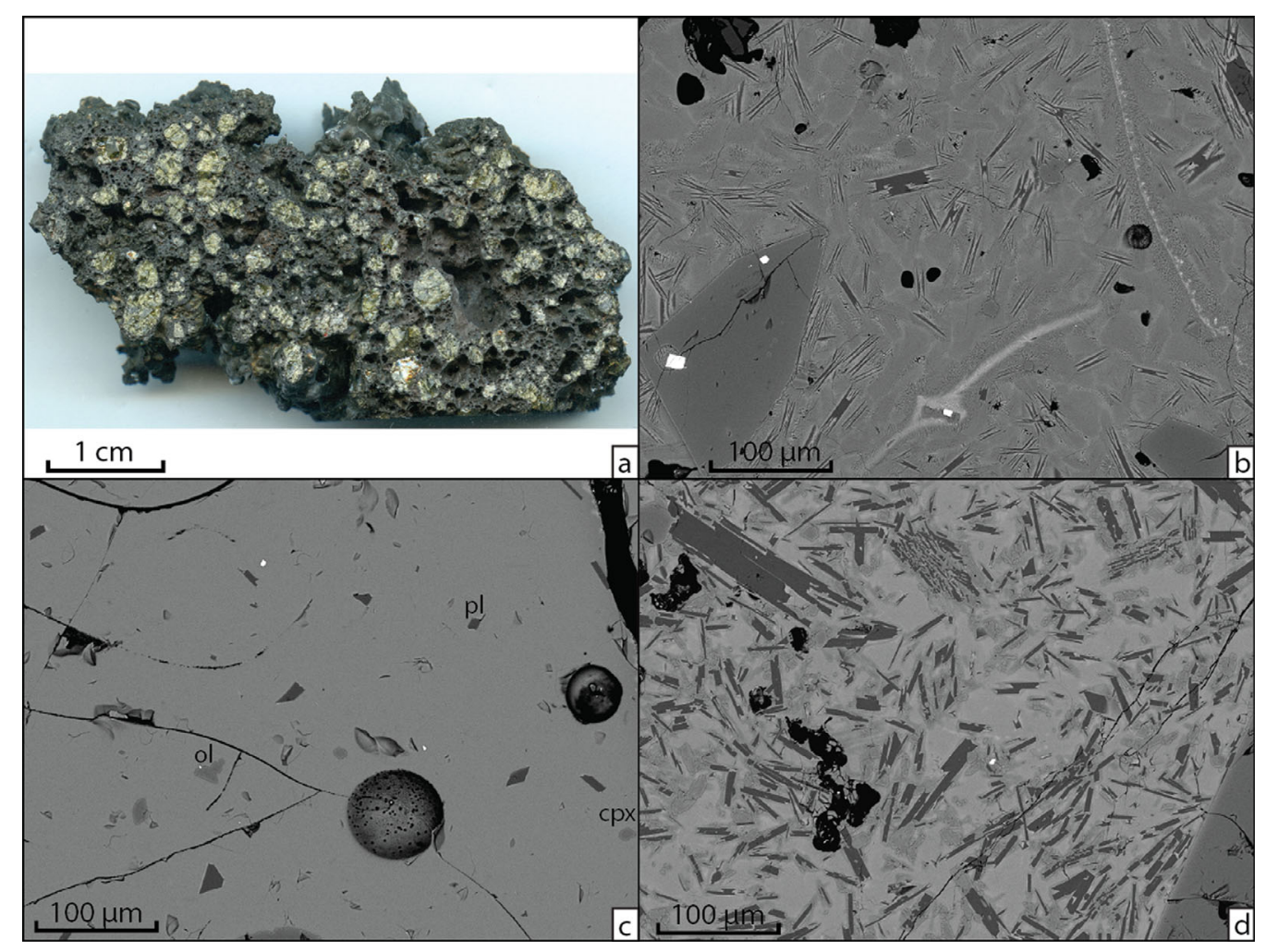

Figure 6. (a) Macroscopic sample rich in olivine macrocrysts and SEM images of the at-vent (PF07-01) and flow front (PF07-15) samples: (b) is the interior of the at-vent sample $200 \mu \mathrm{m}$ from the crust; (c) is the crust of the same sample, and (d) is the crust of the flow front sample. 
benches of stagnant lava from the central plug of 'a'a flow. The surface crust comprises rounded and abraded 'a'a clasts, plus lava balls and boats of pahoehoe from higher up in the system (Figure 3d), the leves being constructed of the same material. Small (1-4 m wide) zones of spiny pahoehoe can be found within the 'a'a of the central plug due to upwelling of coherent lava from the flow interior. Flow width is 10 times wider than in zone A. Zone C of the North Channel is $54 \mathrm{~m}$ wide near RN2, narrowing to $36 \mathrm{~m}$ near the flow front. Here levées are around $1 \mathrm{~m}$ high and flow is brim-full. Thus, the flow depth is of the order of the levee height, i.e., $0.8-1 \mathrm{~m}$. At these locations, flows are of distal 'a'a.

\subsubsection{Zone $D$}

A 12-20 m long section of dispersed flow separates channelized zone $C$ from the flow front in both channels. Given the system length of $850 \mathrm{~m}$, this means that just 1-2\% of the flow is dispersed by length. Flow fronts were of distal 'a'a clasts, lava balls and lava boats of pahoehoe, lying at angle of repose $\left(35^{\circ}-40^{\circ}\right)$. Flow fronts were 1.5-2.5 m high, 2-4 $\mathrm{m}$ long (in the down-flow direction) and fed late-stage breakouts of spiny pahoehoe and 'a'a. The flow front fed by the South Channel has a relatively simple form, and fed just two short flows of spiny pahoehoe that oozed out of flow front breccia near the base of the flow. The shortest unit is $4 \mathrm{~m}$ long and $1.5 \mathrm{~m}$ in width; the longest is $16 \mathrm{~m}$ long and $0.8 \mathrm{~m}$ width (Figure 5). In contrast, the flow front fed by the North Channel has a complex morphology, with six subunits extending from the flow front associated with a complicated emplacement sequence involving emission of spiny pahoehoe from flow front boccas and flow front failure to feed further flow for up to $35 \mathrm{~m}$ beyond the flow front (Figure 5).

\subsection{Lava-Flow Texture, Chemistry, and Temperature}

The peculiar characteristic of oceanite lavas is the very high content of olivine macrocrysts (Figure 6a) which, in our samples, ranges from $43 \%$ to $60 \%$. This is in agreement with values of to $45 \%$ and $58 \%$ obtained by Di Muro et al. [2014] for April 2007 lava samples. A few rare, isolated mesocrysts of olivine, or an assemblage of clinopyroxene and plagioclase, can be observed, but the macrocrysts of olivine are mostly dispersed in a groundmass formed of microcrysts of olivine + clinopyroxene + plagioclase. Also apparent is a very late-stage microcryst population, with dimensions of $<30 \mu \mathrm{m}$ and comprising tiny fibrous or dendritic overgrowths on microcrysts of olivine + clinopyroxene + plagioclase + Fe-Ti oxides. If we compare the glassy crust of at-vent sample PF07-01 with the boundary between the crust and the interior of the same sample (cf., Figures $6 \mathrm{~b}$ and $6 \mathrm{c}$ ), we see a difference in crystallinity that points to postemplacement crystallization of the interior. The interior contains many more crystals than the crust, and these crystals are all characterized by a skeletal shape which is characteristic of crystals grown during fast cooling at high oversaturation, i.e., undercooling (Figure 6b). In contrast, crystals in the crust are characterized by a polyhedral shape indicating slower cooling [Faure et al., 2003]. There is almost no glass in the interior due to dendrite crystallization. Thus, while crystals of the crust are those that were present upon eruption, plus any that were grown down-flow, those of the interior are dominated by postemplacement crystallization during slow cooling after flow.

\subsubsection{Crystal Size Distributions: Vent Versus Flow Front}

If we compare the crystal size distribution for a near-vent and a flow front crust sample, we observe that both samples are characterized by three crystal size populations (Figure 7). The first, dominant, population has a mean equivalent diameter of between 3 and $4 \mathrm{~mm}$ and is entirely composed of large olivines. This population represents the macrocryst olivines. The second population has a smaller, narrower distribution and is formed by scarce isolated mesocrysts of olivine or assemblages of clinopyroxene and plagioclase. The third population is formed by microcrysts of olivine, plagioclase, and pyroxene. This population is well defined for the flow front sample, but not well defined in the at-vent sample (Figure 7). This observation is consistent with the microcryst population in the flow-front sample representing crystals grown during flow. Instead, the at-vent sample resembles the rapidly quenched samples of Di Muro et al. [2014] that are rare in microlites because they have had no time to grow. Those that are present are those that have grown in the chamber [Peltier et al., 2009; Lénat et al., 2012] or during ascent [Welsch et al., 2009], and represent a very small percentage of the total (Figure 7).

\subsubsection{Chemistry and Down-Flow Temperature}

The 2007 lava falls within the Mg-rich oceanite domain defined by Lénat et al. [2012]. Bulk MgO content increases down-flow from $26 \%$ at the vent, to nearly $30 \%$ at the flow front (Table 1). Glass MgO content, however, decreases down-flow (Table 2) which (following equation (1)) means that lava temperature decreased down-flow (Table 4). Down the first $400 \mathrm{~m}$ of the system, temperature decreases linearly, at an average cooling rate (per unit distance) of $6.8^{\circ} \mathrm{C} \mathrm{km}^{-1}$, from around $1167^{\circ} \mathrm{C}$ at the vent (Figure 8a). This 


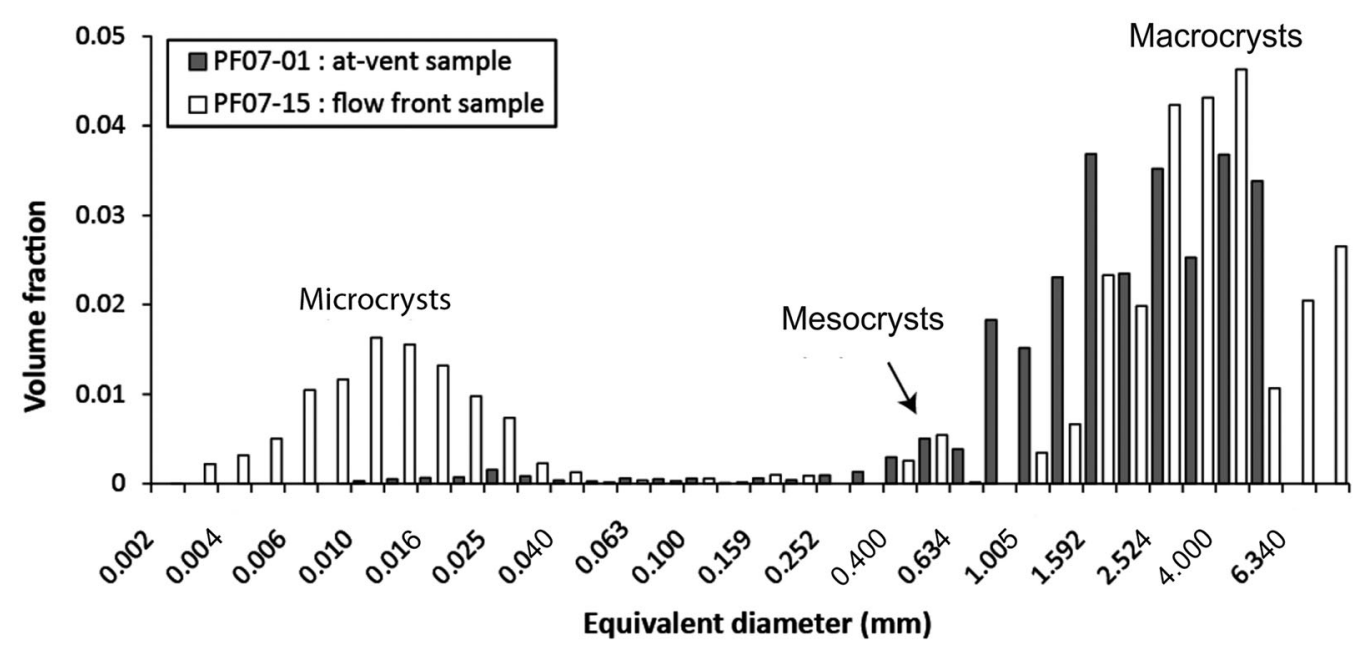

Figure 7. Crystal size distribution of at-vent sample PF07-01 and flow front sample PF07-15.

compares with the cooling rate of $6.7^{\circ} \mathrm{C} \mathrm{km}^{-1}$ obtained by Robert et al. [2014] for a lava channel on Kilauea and is similar to the rate of $5-7^{\circ} \mathrm{C} \mathrm{km}^{-1}$ obtained over the first $10 \mathrm{~km}$ of the $27 \mathrm{~km}$ long lava flow of Mauna Loa's 1984 eruption [Crisp et al., 1994], as well as $5.6^{\circ} \mathrm{C} \mathrm{km}^{-1}$ down the first $10 \mathrm{~km}$ of the Mauna Loa 1859 channel [Riker et al., 2009]. Unfortunately, we lack data around $600 \mathrm{~m}$ from the vent, because the road is built over the lava and there is a large amount of man-made grading for around $25 \mathrm{~m}$ either side of the road. But below the road temperature displays a degree of scatter, with a different trend apparent in the two sampled channels (Figure 8a). The North Channel has higher temperatures than the South Channel and has a trend that plots more or less on the continuity of the $6.8^{\circ} \mathrm{C} \mathrm{km}^{-1}$ trend found over the first $400 \mathrm{~m}$, but the cooling rate in the North Channel increases to $42^{\circ} \mathrm{C} \mathrm{km}^{-1}$ after $475 \mathrm{~m}$ (Table 4).

\subsubsection{Down-Flow Vesicularity and Crystallinity}

With the exception of four anomalous data points, density increases linearly with distance from the vent (Figure $8 \mathrm{~b}$ ), so that vesicularity decreases from $57 \%$ at the vent to $45 \%$ at the flow front. This trend indicates that the lava slowly loses vesicles as it flows, becoming denser toward the flow front [Lipman and Banks, 1987; Riker et al., 2009].

If we compare the crystal contents obtained with FOAMS with that obtained from the mass balance method, we find that the results are in good agreement (Figure $8 \mathrm{c}$ ). Across zones A and B microphenocryst content increases from $1.8 \pm 1.1 \%$ near the vent to around $12 \%$ at $400 \mathrm{~m}$. In zone $\mathrm{C}$, a difference in behavior between the North and South Channels is again evident. While the crystallinity of the North Channel increases at roughly the same rate out to $800 \mathrm{~m}$, the increase in crystal content experienced by the South Channel is more pronounced, attaining a microphenocryst content (corrected for vesicularity) at the flow front of $26 \pm 3 \%$. The results for the South Channel are the same as those of Robert et al. [2014] for a lava channel on Kilauea (Hawaii), and can be explained by down-flow cooling [see also Cashman et al., 1999; Harris and Rowland, 2001, 2015], as can be seen here through comparison with the temperature trend (cf., Figures $9 \mathrm{a}$ and 9c). Because the temperature decrease down the South Channel is greater than that down the North Channel, the microcryst content reaches higher values in the South Channel than in the North Channel. Most of the new crystals are plagioclase (around 60\%), with olivine and clinopyroxene (40\%).

FOAMS-based calculations give a macrocryst content (corrected for vesicularity) of $56 \pm 6 \%$ for the at-vent sample and $48 \pm 5 \%$ for the flow front samples (Figure $8 \mathrm{~d}$ ), indicating a higher content of macrocrysts near the vent. In contrast, macrocryst content obtained from the apparent DRE density increases down-flow (Figure $8 d$ ), a result consistent with the mass balance approach. These two contrasting trends are due to the very large sizes of these crystals. As argued by Gurioli et al. [2014], it is difficult to be fully representative of the extreme ends of a distribution, especially in this case where the coarse end of the distribution is 

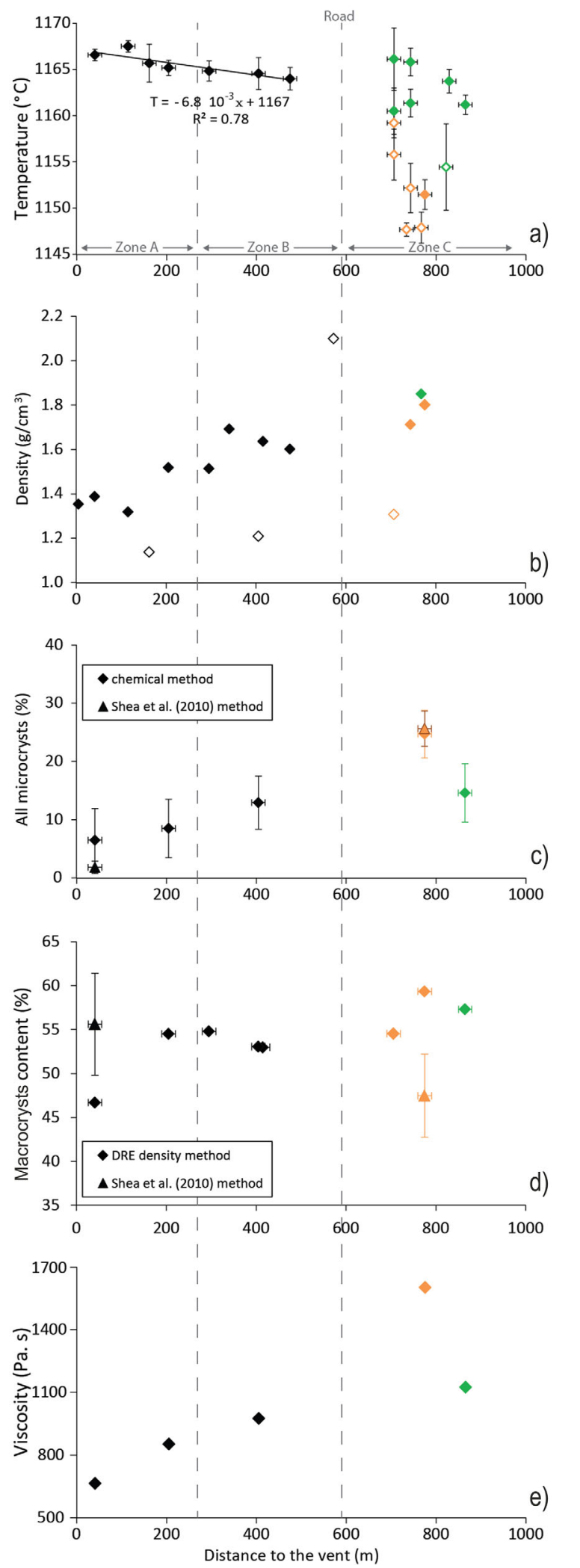

Figure 8. (continued) characterized by outsized objects. The qualitative CSD in Figure 7 shows clearly how the distribution is chaotic and ends abruptly and how the presence of just one or two macrocrysts can shift the distribution. We thus favor the DRE method because of its capability to improve the statistics by considering a greater volume of lava. Furthermore, samples PF0706d and PF07-07 are taken almost at the same distance from the vent (405 and $415 \mathrm{~m}$, respectively), but in two different channels. They give almost the same macrocryst content $(56.5 \%$ and $56.6 \%$, respectively) with the apparent DRE density method, suggesting that these measurements are representative and valid. Therefore, it seems more plausible that the megaolivine content increases down-flow from around $43 \%$ near the source to $55-60 \%$ toward the flow front (these values are corrected for vesicularity). This is an increase in macrocryst content by around 15\% between the source and the flow front.

\subsection{FLOWGO Modeling: Velocity, Effusion Rate, and Rheology}

FLOWGO was initialized with the average content of macrocrysts (24\%, noncorrected for vesicularity) and an at-vent lava depth of $1 \mathrm{~m}$. For this braided case, where the vent-outlet channel divides into two or more branches which then merge again, FLOWGO is a perfect framework because the model is independent of flow width. Instead down-system evolution of the control volume depends on a single channel dimension: flow depth. Once the control volume has been erupted into a ventoutlet (master) channel of depth $d$ and width $w$, effusion rate $\left(E_{r}\right)$ is then obtained from the calculated velocity $\left(v_{\text {mean }}\right)$ in $E_{r}=d w v_{\text {mean }}$. To conserve volume down system, depth is held constant and width is varied as velocity

Figure 8. Temperature, density, crystallinity (corrected for vesicularity), and viscosity as a function of distance downflow. Black symbols are samples located in zones $A$ and $B$; orange symbols are samples from zone $C$ of the South Channel (as separated by dashed line). Green symbols denote samples from zone $\mathrm{C}$ of the North Channel. Empty symbols mark samples for which $\mathrm{K}_{\mathrm{D}}<0.30$. Note: in terms of temperature, the first seven samples give a good trend. Thus, we assume that the liquid is in equilibrium with the olivines for these samples. These samples have an olivine/liquid $\mathrm{Fe} / \mathrm{Mg}$ equilibrium constant $\left(K_{D}\right)$ of $0.33 \pm 0.03( \pm 2 \sigma)$. This range is in agreement with generally accepted equilibrium values [e.g., Toplis, 2005]. Thus, data with $\mathrm{K}_{\mathrm{D}}$ less than 0.30 are not entirely trustworthy. Six samples below the road have $\mathrm{K}_{\mathrm{D}}$ below this value. 

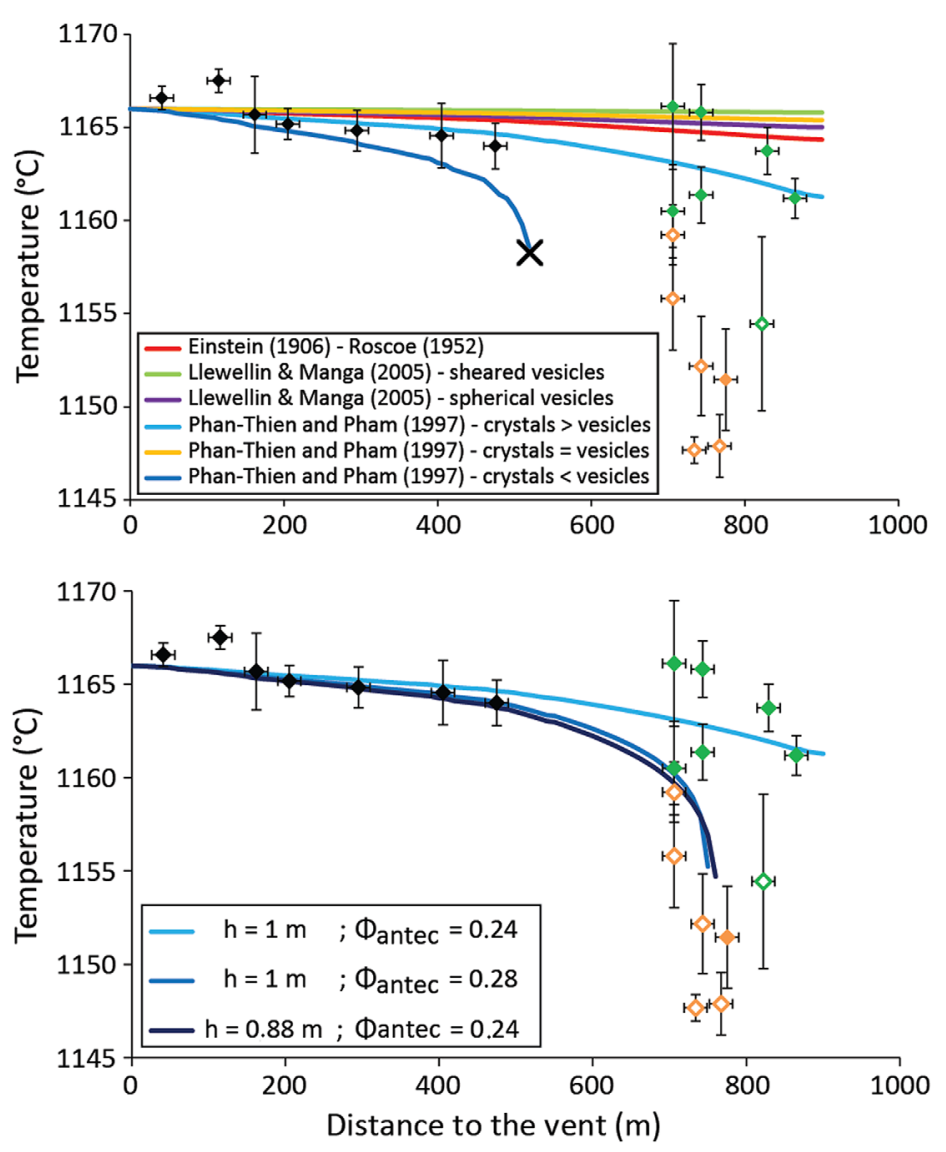

Figure 9. FLOWGO fits to down-flow temperature data using the three-phase viscosity of relations of equations (6a)-(6c) for (a) the North Channel, for which we also compare with fits obtained using Einstein-Roscoe [1952] and Llewellin and Manga [2005], and (b) the South Channel. Not plotted are Mueller et al. [2010] (case = crystal aspect ratio 1:4) and Costa et al. [2009] (case = spherical crystals), which plots on the trend given by the threephase model (case $=$ crystals and vesicles are of the same size, and Costa et al. [2009] (case $=$ elongated crystals), which plots on the three-phase trend (case $=$ crystals smaller than vesicles). See Figure 8 for key to symbol colour and fill. position. In contrast, the North Channel run yields an at-vent velocity of $2.6 \mathrm{~m} \mathrm{~s}^{-1}$ and an effusion rate of $10.5 \mathrm{~m}^{3} \mathrm{~s}^{-1}$, but stops at $1160 \mathrm{~m} ; 300 \mathrm{~m}$ beyond the actual flow front position.

\subsubsection{Lava Viscosity and Yield Strength}

Best-fitting with flow temperature also revealed that the three-phase model of Phan-Thien and Pham [1997] (case $=$ crystals larger than vesicles) provided the best fit (Figure 9). While, for the case where crystals and vesicles are of the same size cooling rates were a little too slow, cooing rates for the case where crystals are smaller than vesicles were too fast, so that the control volume became rheologically incapable of deformation at a distance just short of $600 \mathrm{~m}$ (Figure 9). Applying the models of Einstein-Roscoe and Llewellin and Manga [2005] (both spherical and deformed vesicle cases), as well as those of Mueller et al. [2010] (case= crystal aspect ratio 1:4) and Costa et al. [2009] (case = spherical crystals), gave similar results to the threephase runs for the case where crystals and vesicles are of the same size. Costa et al. [2009] (case= elongated crystals) gave a result similar to that obtained with the three-phase case where crystals are smaller than vesicles.

For assessment of the likely flow viscosity for the five samples for which we have a crystal content, we thus used equation (7c) of the three-phase viscosity model (Table 5). Viscosity and yield strength increase slowly across the proximal-medial sections of the channel, with lava cooling and crystallization. Across these sections (zones A and B) viscosity increases from $660 \mathrm{~Pa} s$ at the source to $975 \mathrm{~Pa}$ s at $400 \mathrm{~m}$. Across the same distance yield strength increases from 130 to $140 \mathrm{~Pa}$. Across zones $C$ and $D$ of the South Channel viscosities reach $1600 \mathrm{~Pa} \mathrm{~s}$ around $800 \mathrm{~m}$ from the vent. In contrast, viscosities increase linearly down the North 


\begin{tabular}{|c|c|c|c|c|c|c|c|}
\hline $\begin{array}{l}\text { Distance From } \\
\text { the Vent }(\mathrm{m})\end{array}$ & $\begin{array}{l}\text { Channel } \\
\text { Width (m) }\end{array}$ & $\begin{array}{c}\text { Levée } \\
\text { Height (m) }\end{array}$ & Temperature $\left({ }^{\circ} \mathrm{C}\right)$ & $\begin{array}{l}\text { Microcryst } \\
\text { Content (\%) }\end{array}$ & $\begin{array}{c}\text { Vesicularity } \\
\text { (\%) }\end{array}$ & $\begin{array}{l}\text { Viscosity } \\
\text { (Pa s) }\end{array}$ & $\begin{array}{c}\text { Yield } \\
\text { Strength }(\mathrm{Pa})\end{array}$ \\
\hline 40 & 2.7 & 0.4 & 1167 & 1.1 & 57 & 660 & 130 \\
\hline 205 & 7.0 & 0.8 & 1165 & 1.4 & 53 & 850 & 130 \\
\hline 405 & 8.0 & 1.2 & 1165 & 1.9 & 62 & 975 & 140 \\
\hline $\begin{array}{l}865 \text { (flow front of } \\
\text { channel N) }\end{array}$ & 17 & 1.5 & 1161 & 3.1 & 45 & 1125 & 160 \\
\hline $\begin{array}{c}775 \text { (flow front of } \\
\text { channel S) }\end{array}$ & 33 & 2.0 & 1151 & 5.0 & 44 & 1600 & 190 \\
\hline
\end{tabular}

Channel to $1100 \mathrm{~Pa} \mathrm{~s}$ at $870 \mathrm{~m}$ from the vent (Figure 8e). We thus have a case where the final, rapidly increasing limb of the distance-dependent viscosity relation is captured in the South Channel, but not in the North Channel. This rheological difference at the two flow fronts is consistent with the yield strength for the end of the South Channel which is $200 \mathrm{~Pa}$, as opposed to $160 \mathrm{~Pa}$ for the North Channel (Table 5). Yield strength estimated on the basis of the South Channel flow front height is $260 \mathrm{~Pa}$ (flow front $\mathrm{h}=1.4 \mathrm{~m}$, density $=1100 \mathrm{~kg} \mathrm{~m}^{-3}$, slope $=1^{\circ}$ ), which is close to that estimated on the basis of temperature and crystallinity at the end of the same channel. If we trust the dimensionally based yield strength to be valid for this control case, then the typical range of flow front heights across the flow field $(1.3-2.3 \mathrm{~m})$, give yield strengths at the end of these channel-fed systems in the range 245-430 Pa.

\subsubsection{Cooling Versus Volume-Limited Flow}

FLOWGO run outs for the North Channel (Figure 9a) are 35\% longer than the actual flow length. Measured and modeled crystallinity, temperature, and viscosity trends for the North Channel are also linear downflow, with no abrupt change in crystallization, cooling, or viscosity toward the flow front (Figure 9), where cooling, crystallization and viscosity trend to exponential toward the flow front in cooling-limited flows [Harris and Rowland, 2001, 2015]. Likewise, field data and experimental results indicate that exponential increases in crystallinity [Cashman et al., 1999] and viscosity [Kolzenburg et al., 2016] should be expected as the cooling process reaches its limit down an active lava channel. In contrast, FLOWGO run outs for the South Channel (Figure 9b) are the same distance as the actual flow, with cooling, crystallization and viscosity trends having the expected exponential (decaying or increasing) trend (Figure 8). We suggest that the former is a trend associated with volume-limited flow, and the latter with cooling-limited flow, with the North Channel stopping at a point where, rheologically, it was still capable of further advance.

\section{Discussion}

Our aim has been to (i) support and build on the channel-fed flow system proposed by Lipman and Banks [1987], (ii) set the system in the context of both cooling-limited and volume-limited flow conditions, and (iii) define the textural, thermal and rheological trends down an L\&B system. As at other channel-fed systems, we are able to define the four segments of the L\&B system, and find that whether the system is built under cooling-limited or volume-limited conditions determines (i) the length of the zone of dispersed flow, (ii) the form of the down-system trend in cooling rate and viscosity, and (iii) the complexity of the flow front.

\subsection{Length of the Zone of Dispersed Flow}

The dispersed flow segment is extremely short in both of the L\&B systems examined here, being just 12$20 \mathrm{~m}$ long (of which the flow front comprises 2-4 m) so that dispersed flow accounts for less than $2 \%$ of the total channel system by length. This contrasts with the dispersed flow described by Lipman and Banks [1987] during Mauna Loa's 1984 eruption which comprised $20-40 \%$ of the total flow system by length. Likewise, at the June 1974 lava flow of Mauna Ulu (Kilauea), dispersed flow accounts for $32 \%$ of the flow length [Harris et al., 2009]. These differences can be due to the fact that, while our flow is volume limited, the 1984 Mauna Loa and 1974 Mauna Ulu lava flows were cooling limited. In the case of a volume-limited flow, the channel will still be in construction and extending forward just behind the flow front when supply is cut and system morphology frozen in place. Instead, in the case of cooling-limited flow, the channel is able to build to its maximum extent, and is stable for a period of time long enough to feed a longer zone of dispersed flow, or a fan of dispersed flow lobes beyond its mouth. 
5.2. Down-System Thermal and Rheological Trends

Over the first $400 \mathrm{~m}$ of the system we have a cooling rate of $6.8^{\circ} \mathrm{C} \mathrm{km}^{-1}$ and an increase in microphenocryst content by $0.4 \mathrm{vol} \% \mathrm{~K}^{-1}$. For the medial-distal reach of the North Channel, the cooling rate increases a little to $8.6^{\circ} \mathrm{C} \mathrm{km}^{-1}$, so that the fluid temperature at the flow front is $1165^{\circ} \mathrm{C}$. Microphenocryst content increases over the same $(465 \mathrm{~m})$ distance from $1.9 \%$ to $3.1 \%$, so that the increase in microphenocryst content remains around the same (at $0.3 \mathrm{vol} \% \mathrm{~K}^{-1}$ ). However, for the medial-distal reach of the South Channel the cooling rate increases to $42^{\circ} \mathrm{C} / \mathrm{km}$, although the rate of increase in microphenocryst content remains around the same at $0.2 \mathrm{vol} \% \mathrm{~K}^{-1}$.

The cooling rate and crystallinity trend for the North Channel system (Figure 8) results in a flow front viscosity that was still quite low (around $1125 \mathrm{~Pa}$ s) so that the flow was certainly still capable of forward motion when it came to a halt, as indicated by the FLOWGO modeling (Figure 9). In contrast, the cooling rate trend for the South Channel system (Figure 8) undergoes a rapid decline toward the flow front, with viscosity also falling in an exponential fashion through 1160 Pa s toward the flow front. This trend fits the expected decay in viscosity expected for a cooling-limited flow when modeled by FLOWGO (Figure 9). We thus suggest that while the thermorheological trend of the North Channel is that of a volume-limited L\&B system, that of the South Channel is that of a cooling-limited L\&B system.

\subsection{Flow Front Morphology}

The result of hot, fluid lava being resident in the flow just behind the stalled volume-limited flow front results in reorganization of that flow front, as is apparent for the flow front at the North Channel. Breakouts from the flow front begin to (i) destroy the simple, single-lobe form of the flow front, (ii) reduce the slope of the flow front, and (iii) creates a compound-flow field, albeit of limited length and of the same width as the feeding flow front, of multiple, stacked up and overlapping units beyond the limit of the initial flow front (Figure 5). The result is a double flow front. The first is relatively low and has a compound form. The second is found a little further back-up flow, has a low angle $\left(20^{\circ}\right)$, and is embayed (due to failure events). This is the initial flow front modified by secondary flow which has carried away the breccia that was emplaced when the flow first came to a halt. Instead, the flow front of the cooling-limited flow, as is the case for the flow front at the South Channel, is a well-formed, simple lobe with a front lying at an angle of $35^{\circ}-40^{\circ}$ (Figure 5).

\subsection{Conceptual System Emplacement Model}

Our measurements and observations allow us to draw up a semiquantitative conceptual model for emplacement of the two L\&B channel systems analyzed here. Key to this model is a time-varying supply whereby high effusion rate pulses overwhelm the tube capacity to cause overflow at the skylight which feeds each flow emplacement event. Such variable flow in tubes is well known, as apparent from multiple level markers found in tubes [Calvari and Pinkerton, 1999]. It has also been observed and documented associated with changes in supply from the vent in lava channels and tubes on Etna [Bailey et al., 2006; Favalli et al., 2010b] and Kilauea [Harris et al., 2009; Orr, 2010] but may also be caused due to back-up of lava during temporary blockage events. Given that 15 units can be counted down the man-made drainage ditch, the flow field was created during a series of at least 15 overflow events. In each event, L\&B channel systems were fed, some of which were cooling limited and some of which were volume limited. In each case, supply to the system would have been abruptly cut when flow in the tube fell below the level of the sky-light. In this way, step by step, a lava shield was built around the skylight vent with a compound lava-flow field of 'a'a channels developing in a $400 \mathrm{~m}$-wide sector between the shield and the coast (Figure 10).

Each pulse would have had a different effusion rate, and the intensity of these pluses appears to have decreased with time. Long, thick systems which reached the Ocean were emplaced first; forming the base of the sequence, these being the $13 \mathrm{~m}$ thick columnar jointed units found at the lower end of the manmade ditch. FLOWGO modeling reveals that flow needed to be fed at rates of at least $14 \mathrm{~m}^{3} \mathrm{~s}^{-1}$ to reach the coast. The pulses became less powerful with time so that shorter, thinner $(1.3 \pm 0.6 \mathrm{~m})$ units were emplaced in the upper NE sector of the flow field, where they buried the proximal sections of the earlier units (Figure 10). These later flows were fed at effusion rates of between 7 and $10 \mathrm{~m}^{3} \mathrm{~s}^{-1}$ and include the two L\&B systems (the North and South Channels) considered here.

The North Channel system was formed by a stronger pulse (of $10 \mathrm{~m}^{3} \mathrm{~s}^{-1}$ ) than the South Channel $\left(7 \mathrm{~m}^{3}\right.$ $\mathrm{s}^{-1}$ ), but the pulse that fed the North Channel did not last long enough to allow it to reach its maximum, 


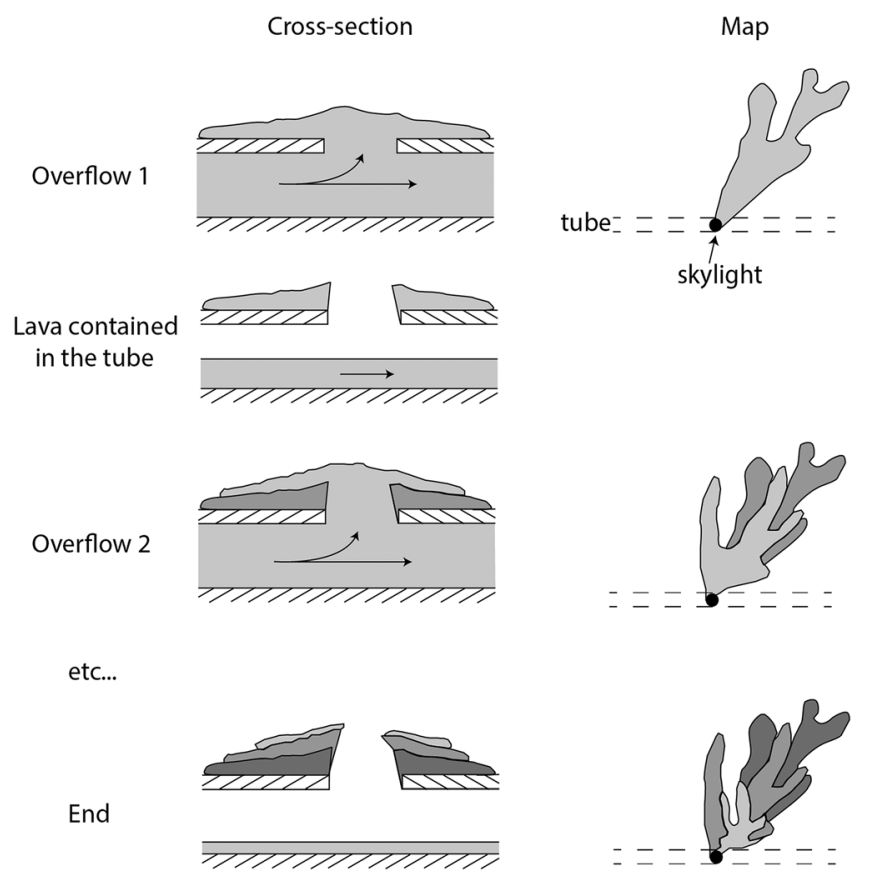

Figure 10. Conceptual model for construction of the rootless shield and lava-flow system of the skylight vent. cessation of supply at the skylight vent would have been forced by flow levels in the tube dropping below the level required for overflow (Figure 10), where-as flow levels declined toward the end of an overflow event-we would expect such a phase of waning effusion rate. Thus, we argue, that a short length of dispersed flow can be associated with both cooling-limited and volume-limited flow. In such cooling-limited cases, the system was frozen in place (and supply was cut) just at the moment that the cooling-limited length was reached, giving no time to feed a zone of dispersed 'a'a flow at the mouth of the channel. This implies that flows with longer dispersed flow zones have greater durations of supply, with the dispersed flow zone only forming after the channel has achieved its full cooling-limited length.

\subsection{A Note on Macrocryst Content and Flow Transport Capacity}

Macrocrysts would have been passively transported in the flow, in a manner similar to that whereby sediments are transported by a river [e.g., Strahler and Strahler, 1973]. As a result, more energetic (high effusion rate and velocity) flow was more capable of transporting macrocrysts than less energetic flow. Therefore, the macrocryst content is higher in flow fed at higher effusion rates. Close to the vent we sampled the last lava to be supplied to the system, fed at waning effusion rates as the overflow event died out. Hence they are less rich in macrocrysts. Further down the system, we sampled lava supplied the onset of the overflow at higher effusion rates, and thus also higher energies and transport capacities. Because of this dynamic, we record a macrocryst content which undergoes an apparent increase down the flow field. This is consistent with the results of Peltier et al. [2009] and Di Muro et al. [2014] who show that the amount of macrocrysts carried by lava erupted during effusive events at Piton de la Fournaise varies as a function of effusion rate. In short, as the ability of the erupted flux to carry a load of heavier and larger particles increases, so too does the presence of the load (macrocryst) component.

\section{Conclusion}

Our data and modeling indicate that, although the channel-fed lava-flow system of Lipman and Banks [1987] can be universally applied, there are some modifications that need to be added. First, in the proximal, stable channel zone, flow will be braided if slope is steep [Dietterich and Cashman, 2014]. In our case, channel morphology changed abruptly with a break-in-slope, where braided, narrow pahoehoe channels with below-bank flow switched to wider, simple (single) 'a'a channels with near-brim-full flow on shallower 
slopes. Second, we can identify a zone of dispersed flow, but it is extremely short. This is the result of volume-limited flow so that the system was frozen in place when the channel was still in extension. However, zones of dispersed flow can also be short in cooling-limited systems, if supply wanes just as the channel attains maximum length, there then being no time to build a distal dispersed flow zone beyond the channel mouth. Third, volume-limited flow means that there is fluid capable of further flow within the flow front storage zone, so that secondary flow from the stalled front of the volume-limited unit increases the complexity of the flow front morphology.

We find that, toward the flow front of a cooling-limited L\&B system, temperatures crash over a very short distance near the flow front so that viscosity and yield strength increase exponentially placing a rheological limit on further flow advance, essentially causing the flow to stop. In contrast, in a volume-limited L\&B system, cooling rates are steady, low and of the order of $5-7^{\circ} \mathrm{C} / \mathrm{km}$ and the exponentially increasing limb of the down-flow cooling rate and viscosity trend is missing. Density and crystallinity also increase steadily, hence so too does lava viscosity and yield strength, a trend which continues to the flow front. In this case, flow stops because supply is cut. In our case, volume limit was due to variable supply from a discontinuously overflowing skylight, with the cessation of each overflow starving a system of supply; thereby forcing cessation of flow front advance. We suggest that morphological, textural, thermal, and rheological trends defined here are typical of L\&B systems that develop under conditions where supply is cut while a channel is still in extension. Our data and simple models also indicate that, whether a L\&B system has a volumelimited or cooling-limited character depends on the rheological state of the lava at the flow front when the supply was cut.

To make this definition requires integration of morphological, chemical, textural, cooling rate, rheological, and dynamical models so as to test, and assess, down-system thermal and rheological trends. We have defined two end-member thermal and rheological trends within which results from such tests can be placed. While the cooling-limited trend is characterized by an exponential form, the volume limited by a small and steady, approximately linear, increase. One-dimensional thermorheological models, such as FLOWGO, complete their runs through a stopping condition whereby the control volume has cooled and/or crystallized through the point at which forward motion is no longer possible. This produces the cooling rate and viscosity trends down a cooling-limited L\&B system. Data that do not produce such a trend thus apply to a volume-limited L\&B system whose forward development was arrested due to cessation of supply at the head of the system.

\section{Acknowledgments}

Field work by A.J.L.H. and M.R. was funded by ANR-STRAP. We thank Hannah Dietterich and an anonymous reviewer for comments that greatly aiding in defining the focus of this paper, which is dedicated to the landmark study of Peter Lipman and Norman Banks during Mauna Loa's 1984 eruption. All data used here are provided as part of the tables and appendices associated with this submission. Supporting information is available from data repository DYNVOLC (http://wwwobs.univbpclermont.fr/SO/televolc/dynvolc/ index.php).

\section{References}

Bachèlery, P., F. Saint-Ange, N. Villeneuve, B. Savoye, A. Normand, E. Le Drezen, A. Barrère, J.-P. Quod, and C. Deplus (2010), Huge lava flows into the sea and caldera collapse, April 2007, Piton de la Fournaise volcano, in IAVCEI Third Workshop on Collapse Calderas Abstracts Volume, pp. 73-74, La Réunion, France.

Bachèlery, P., J.-F. Lénat, A. Di Muro, and L. Michon (2016), Active Volcanoes of the Southwest Indian Ocean: Piton de la Fournaise and Karthala, Active Volcanoes of the World, IACVEl, 423 pp., Springer, Berlin.

Bailey, J. E., A. J. L. Harris, J. Dehn, S. Calvari, and S. K. Rowland (2006), The changing morphology of an open lava channel on Mt. Etna, Bull. Volcanol., 68, 497-515, doi:10.1007/s00445-005-0025-6.

Ball, M., H. Pinkerton, and A. J. L. Harris (2008), Surface cooling, advection and the development of different surface textures on active lavas at Kilauea, Hawaii, J. Volcanol. Geotherm. Res., 173, 148-156.

Calvari, S., and H. Pinkerton (1999), Lava tube morphology on Etna and evidence for lava flow emplacement mechanisms, J. Volcanol. Geotherm. Res., 90, 263-280, doi:10.1016/S0377-0273(99)00024-4.

Cashman, K. V., C. Thornber, and J. P. Kauahikaua (1999), Cooling and crystallization of lava in open channels, and the transition of Pahoehoe Lava to 'A'a, Bull. Volcanol., 61, 306-323, doi:10.1007/s004450050299.

Cimarelli, C., A. Costa, S. Mueller, and H. M. Mader (2011), Rheology of magmas with bimodal crystal size and shape distributions: Insights from analog experiments, Geochem. Geophys. Geosyst., 12, Q07024, doi:10.1029/2011GC003606.

Costa, A., L. Caricchi, and N. Bagdassarov (2009), A model for the rheology of particle-bearing suspensions and partially molten rocks, Geochem. Geophys. Geosyst., 10, Q03010, doi:10.1029/2008GC002138.

Crisp, J., K. V. Cashman, J. A. Bonini, S. B. Hougen, and D. C. Pieri (1994), Crystallization history of the 1984 Mauna Loa lava flow, J. Geophys. Res., 99, 7177-7198, doi:10.1029/93JB02973.

Di Muro, A., N. Metrich, D. Vergani, M. Rosi, P. Armienti, T. Fougeroux, E. Deloule, L. Arienzo, and L. Civetta (2014), The shallow plumbing system of Piton de la Fournaise Volcano (La Reunion Island, Indian Ocean) revealed by the major 2007 caldera-forming eruption, J. Petrol., 55(7), 1287-1315, doi:10.1093/petrology/egu025.

Dietterich, H. R., and K. V. Cashman (2014), Channel networks within lava flows: Formation, evolution, and implications for flow behavior, J. Geophys. Res. Earth Surf., 119, 1704-1724, doi:10.1002/2014JF003103.

Dragoni, M. (1989), A dynamical model of lava flows cooling by radiation, Bull. Volcanol., 51, 88-95.

Famin, V., B. Welsch, S. Okumura, P. Bachélery, and S. Nakashima (2009), Three differentiation stages of a single magma at Piton de la Fournaise (Reunion hotspot), Geochem. Geophys. Geosyst., 10, Q01007, doi:10.1029/2008GC002015.

Favalli, M., A. J. L. Harris, A. Fornaciai, M. T. Pareschi, F. Mazzarini (2010a), The distal segment of Etna's 2001 basaltic lava flow, Bull. Volcanol., 72, 119-127, doi:10.1007/s00445-009-0300-z. 
Favalli, M., A. Fornaciai, F. Mazzarini, A. Harris, M. Neri, B. Behncke, M. T. Pareschi, S. Tarquini, and E. Boschi (2010b), Evolution of an active lava flow field using a multitemporal LIDAR acquisition, J. Geophys. Res., 115, B11203, doi:10.1029/2010JB007463.

Fisher, G. W., and L.G. Medaris Jr. (1969), Cell dimensions and X-ray determinative curve for synthetic Mg-Fe olivines, Am. Mineral., $54,741-753$.

Guest, J. E., C. R. J. Kilburn, H. Pinkerton, and A. M. Duncan (1987), The evolution of lava flow-fields: Observations of the 1981 and 1983 eruptions of Mount Etna, Sicily, Bull. Volcanol., 49, 527-540.

Gurioli, L., L. Colo', A. J. Bollasina, A. J. L. Harris, A. Whittington, and M. Ripepe (2014), Dynamics of Strombolian explosions: Inferences from field and laboratory studies of erupted bombs from Stromboli volcano, J. Geophys. Res. Solid Earth, 119, 319-345, doi:10.1002/ 2013JB010355.

Harris, A. J. L., and S. K. Rowland (2001), FLOWGO: A kinematic thermo-rheological model for lava flowing in a channel, Bull. Volcanol., 63, 20-44, doi:10.1007/s004450000120.

Harris, A. J. L., and S. K. Rowland (2009), Effusion rate controls on lava flow length and the role of heat loss: A review, in Studies in Volcanology: The Legacy of George Walker, edited by T. Thordarson et al., Spec. Publ. of IAVCEI, 2, 33-51.

Harris, A. J. L., and S. K. Rowland (2015), FLOWGO 2012, in Hawaiian Volcanoes, edited by R. Carey et al., pp. 457-481, John Wiley, Hoboken, N. J.

Harris, A. J. L., J. Dehn, and S. Calvari (2007), Lava effusion rate definition and measurement: A review, Bull. Volcanol., 70, 1-22, doi:10.1007/ s00445-007-0120-y.

Harris, A. J. L., M. Favalli, F. Mazzarini, and C. W. Hamilton (2009), Construction dynamics of a lava channel, Bull. Volcanol., 71, 459-474, doi: 10.1007/s00445-008-0238-6.

Harris, A. J. L., M. Rhéty, L. Gurioli, N. Villeneuve, and R. Paris (2016), Simulating the thermo-rheological evolution of channel-contained lava: FLOWGO and its implementation in EXCEL, in Detecting, Modelling and Responding to Effusive Eruptions, edited by A. J. L. Harris et al., Geol. Soc., London, Spec. Publ., 426, 313-336, doi:10.1144/SP426.9.

Harris, A. J. L., S. K. Rowland, N. Villeneuve, and T. Thordarson (2017), Pāhoehoe, 'a'ā, and block lava: An illustrated history of the nomenclature, Bull. Volcanol., 79, 7, doi:10.1007/s00445-016-1075-7.

Heath, T. L. (1897), The Works of Archimedes, 369 pp., Cambridge Univ. Press, Cambridge, U. K.

Helz, R. T., and C. R. Thornber (1987), Geothermometry of Kilauea Iki lava lake, Hawaii, Bull. Volcanol., 49(5), pp. 651-668.

Higgins, M. D. (2000), Measurement of crystal size distributions, Am. Miner., 85(9), 1105-1116.

Houghton, B. F., and C. N. J. Wilson (1989), A vesicularity index for pyroclastic deposits, Bull. Volcanol., 51(6), 451-462.

Hulme, G. (1974), The interpretation of lava flow morphology, Geophys. J. Int., 39, 361-383, doi:10.1111/j.1365-246X.1974.tb05460.x.

Kilburn, C. R. J., and J. E. Guest (1993), Aa lavas of Mount Etna, Sicily, in Active Lavas, pp. 73-106, UCL, London, U. K.

Kilburn, C. R. J., and M. C. Lopes (1988), The growth of aa lava flow fields on Mount Etna, Sicily, J. Geophys. Res., 93(B12), 14,759-14,772.

Kilburn, C. R. J., and M. C. Lopes (1991), General patterns of flow field growth: Aa and blocky lavas, J. Geophys. Res., 96(B12), $19,721-19,732$.

Kolzenburg, S., D. Giordano, C. Cimarelli, and D. B. Dingwell (2016), In situ thermal characterization of cooling/crystallizing lavas during rheology measurements and implications for lava flow emplacement, Geochim. Cosmochim. Acta, 195, 244-258, doi:10.1016/j.gca.2016.09.022.

Kress, V. C., and I. S. E. Carmichael (1991), The compressibility of silicate liquids containing $\mathrm{Fe}_{2} \mathrm{O}_{3}$ and the effect of composition, temperature, oxygen fugacity and pressure on their redox states, Contrib. Mineral. Petrol., 108, 82-92.

Lénat, J.-F., P. Bachèlery, and O. Merle (2012), Anatomy of Piton de la Fournaise volcano (La Réunion, Indian Ocean), Bull. Volcanol., 74, 1945-1961, doi:10.1007/s00445-012-0640-y.

Lipman, P. W., and N. G. Banks (1987), 'A'a flow dynamics, Mauna Loa 1984, in Volcanism in Hawaii, U.S. Geol. Surv. Prof. Pap., 1350, $1527-1567$.

Llewellin, E. W., and M. Manga (2005), Bubble suspension rheology and implications for conduit flow, J. Volcanol. Geotherm. Res., 143, 205-217, doi:10.1016/j.jvolgeores.2004.09.018.

Mader, H. M, E. W. Llewellin, and S. P Mueller (2013), The rheology of two-phase magmas: A review and analysis, J. Volcanol. Geotherm. Res., 257, 135-158, doi:10.1016/j.jvolgeores.2013.02.01.

Maron, S. H., and P. E. Pierce (1956), Application of ree-eyring generalized flow theory to suspensions of spherical particles, J. Colloid Sci., 11(1), 80-95.

Michon, L., T. Staudacher, V. Ferrazzini, P. Bachèlery, and J. Marti (2007), April 2007 collapse of Piton de la Fournaise: A new example of caldera formation, Geophys. Res. Lett., 34, L21301, doi:10.1029/2007GL031248.

Michon, L., N. Villeneuve, T. Catry, and O. Merle (2009), How summit calderas collapse on basaltic volcanoes: New insights from the April 2007 caldera collapse of Piton de la Fournaise volcano, J. Volcanol. Geotherm. Res., 184, 138-151.

Moore, H. J. (1987), Preliminary estimates of the rheological properties of 1984 Mauna Loa lava, in Volcanism in Hawaii, U.S. Geol. Surv. Prof. Pap., 1350, 1569-1588.

Mueller, S., E. W. Llewellin, and H. M. Mader (2010), The rheology of suspensions of solid particles, Philos. Trans. R. Soc. A, 466, $1201-1228$.

Orr, T. R. (2010), Lava tube shatter rings and their correlation with lava flux increases at Kîlauea Volcano, Hawai'i, Bull. Volcanol., 73, 335346, doi:10.1007/s00445-010-0414-3.

Peltier, A., P. Bachelery, and T. Staudacher (2009), Magma transport and storage at Piton de la Fournaise (La Reunion) between 1972 and 2007: A review of geophysical and geochemical data, J. Volcanol. Geotherm. Res., 184, 93-108.

Phan-Thien, N., and D. Pham (1997), Differential multiphase models for polydispersed suspensions and particulate solids, J. Non-Newton Fluid. Mech., 72, 305-318, doi:10.1016/S0377-0257(97)90002-1.

Riker, J. M., K. V. Cashman, J. P. Kauahikaua, and C. M. Montierth (2009), The length of channelized lava flows: Insight from the 1859 erup tion of Mauna Loa Volcano, Hawai'i, J. Volcanol. Geotherm. Res., 183, 139-156, doi:10.1016/j.jvolgeores.2009.03.002.

Robert, B., A. J. L. Harris, L. Gurioli, E. Médard, A. Sehlke, and A. Whittington (2014), Textural and rheological evolution of basalt flowing down a lava channel, Bull. Volcanol., 76, 824, doi:10.1007/s00445-014-0824-8.

Roscoe, R. (1952), The viscosity of suspensions of rigid spheres, Br. J. Appl. Phys., 3, 267-269, doi:10.1088/0508-3443/3/8/306

Rowland, S. K., and G. P. L. Walker (1987), Toothpaste lava: Characteristics and origin of a lava structural type transition between pahoehoe and aa, Bull. Volcanol., 49, 631-641.

Ryerson, F. J., H. C. Weed, and A. J. Piwinski (1988), Rheology of subliquidus magmas: 1. Picritic compositions, J. Geophys. Res., 93, 34213436

Shea, T., B. F. Houghton, L. Gurioli, K. V. Cashman, J. E. Hammer, and B. J. Hobden (2010), Textural studies of vesicles in volcanic rocks: An integrated methodology, J. Volcanol. Geotherm. Res., 190, 271-289, doi:10.1016/j.jvolgeores.2009.12.003.

Soule, A. S., K. V. Cashman, and J. P. Kauahikaua (2004), Examining flow emplacement through the surface morphology of three rapidly emplaced, solidified lava flows, Kïlauea Volcano, Hawaii, Bull. Volcanol., 66, 1-14, doi:10.1007/s00445-003-0291-0.

Sparks, R. S. J., H., Pinkerton, and G. Hulme (1976), Classification and formation of lava levees on Mount Etna, Sicily, Geology, 4(5), $269-271$.

Staudacher, T., L. Ruzié, and A. Peltier (2008), Historique des éruptions du Piton de la Fournaise de 1998 à 2007, 97 pp., Graphica, St Denis, La Réunion, France. 
Staudacher, T., V. Ferrazzini, A. Peltier, P. Kowalski, P. Boissier, P. Catherine, F. Lauret, and F. Massin (2009), The April 2007 eruption and the Dolomieu crater collapse, two major events at Piton de la Fournaise (La Réunion Island, Indian Ocean), J. Volcanol. Geotherm. Res., 184, 126-137, doi:10.1016/j.jvolgeores.2008.11.005.

Strahler, A. N., and A. H. Strahler (1973), Evironmental Geoscience: Interaction between natural systems and Man, Hamilton Publishing Company, 511 pp., Santa Barbara, Calif.

Toplis, M. J. (2005), The thermodynamics of iron and magnesium partitioning between olivine and liquid: Criteria for assessing and predicting equilibrium in natural and experimental systems, Contrib. Mineral. Petrol., 149, 22-39, doi:10.1007/s00410-004-0629-4.

Villemant, B., A. Salaün, and T. Staudacher (2009), Evidence for a homogeneous primary magma at Piton de la Fournaise (La Réunion): A geochemical study of matrix glass, melt inclusions and Pélé's hairs of the 1998-2008 eruptive activity, J. Volcanol. Geotherm. Res., 184, 79-92, doi:10.1016/j.jvolgeores.2009.03.015.

Villeneuve, N. (2000), Apports multi-sources à une meilleure compréhension de la mise en place des coulées de lave et des risques associés au Piton de la Fournaise: Géomorphologie quantitative en terrain volcanique, PhD thesis, 374 pp., Inst. de Phys. du Globe de Paris, Paris, France.

Villeneuve, N., D. R. Neuville, P. Boivin, et al (2008), Magma crystallization and viscosity: A study of molten basalts from the Piton de la Fournaise volcano (La Réunion island), Chem. Geol., 256, 242-251, doi:10.1016/j.chemgeo.2008.06.039.

Wadge, G. (1981), The variation of magma discharge during basaltic eruptions, J. Volcanol. Geotherm. Res., 11, 139-168, doi:10.1016/03770273(81)90020-2.

Wadge, G., and R. M. C. Lopez (1991), The lobes of lava flows on Earth and Olympus Mons, Mars, Bull. Volcanol., 54(1), 10-24, doi:10.1007/ BF00278203.

Welsch, B., F. Faure, P. Bachèlery, and V. Famin (2009), Microcrysts record transient convection at Piton de la Fournaise volcano (La Réunion Hotspot), J. Petrol., 50, 2287-2305, doi:10.1093/petrology/egp076.

Welsch, B., F. Faure, V. Famin, and P. Bachèleri (2013), Dendritic crystallization: A single process for all the textures of olivine in basalts?, J. Petrol., 54, 539-574, doi:10.1093/petrology/egs077. 